\title{
The role of imaging in acute ischemic stroke
}

\author{
Elizabeth Tong, M.D., ${ }^{1}$ Qinghua Hou, M.D., Ph.D., ${ }^{1,2}$ Jochen B. Fiebach, M.D., ${ }^{3}$ \\ ANd Max Wintermark, M.D., M.A.S., ${ }^{1,4}$ \\ ${ }^{1}$ Neuroradiology Division, Department of Radiology, University of Virginia, Charlottesville, Virginia; \\ ${ }^{2}$ Department of Neurology, Second Affiliated Hospital of Guangzhou Medical University, Guangzhou, China; \\ ${ }^{3}$ Department of Neurology, Center for Stroke Research Berlin, Charité-Universitätsmedizin Berlin, Campus \\ Benjamin Franklin, Berlin, Germany; and ${ }^{4}$ Department of Radiology, Centre Hospitalier Universitaire \\ Vaudois and University of Lausanne, Switzerland
}

\begin{abstract}
Neuroimaging has expanded beyond its traditional diagnostic role and become a critical tool in the evaluation and management of stroke. The objectives of imaging include prompt accurate diagnosis, treatment triage, prognosis prediction, and secondary preventative precautions. While capitalizing on the latest treatment options and expanding upon the "time is brain" doctrine, the ultimate goal of imaging is to maximize the number of treated patients and improve the outcome of one the most costly and morbid disease. A broad overview of comprehensive multimodal stroke imaging is presented here to affirm its utilization.
\end{abstract} (http://thejns.org/doi/abs/10.3171/2013.10.FOCUS13396)

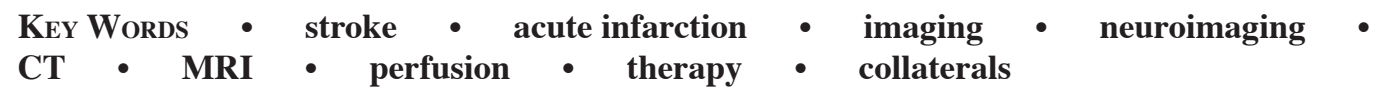

$\mathrm{S}$ TROKE is the fourth leading cause of death in the United States. According to the American Heart Association, 795,000 patients experience a new or recurrent stroke each year in the US, and stroke results in 1 of every 19 deaths ${ }^{63}$ Current treatments for acute ischemic stroke include intravenous (IV) tissue plasminogen activator (tPA), endovascular mechanical recanalization, and intraarterial thrombolysis. The number needed to treat for IV tPA to benefit 1 patient is about $7 .{ }^{47}$ However, less than $5 \%$ of patients with acute stroke receive IV tPA. This is largely due to the narrow time window for treatment (3-4.5 hours for IV tPA, ,2, 21,72,73,125,155 6 hours for intraarterial thrombolysis, ${ }^{92} 8$ hours for endovascular mechanical recanalization ${ }^{159,169,177,193,201}$ ) and delayed presentation to care. ${ }^{3}$

Neuroimaging has become a critical tool in the evalu-

Abbreviations used in this paper: $\mathrm{ADC}=$ apparent diffusion coefficient; ASL = arterial spin-labeling; ASPECTS = Alberta Stroke Program Early CT Score; CBF = cerebral blood flow; CBV = cerebral blood volume; $\mathrm{CTA}=\mathrm{CT}$ angiography; $\mathrm{DSA}=$ digital subtraction angiography; DWI = diffusion-weighted imaging; $\mathrm{GRE}=$ gradient-recalled echo; $\mathrm{IV}=$ intravenous; $\mathrm{MCA}=$ middle cerebral artery; MRA = MR angiography; MTT = mean transit time; $\mathrm{NCHCT}=$ noncontrast head $\mathrm{CT} ; \mathrm{PCT}=$ perfusion $\mathrm{CT} ; \mathrm{PWI}=$ perfusion-weighted imaging; SWI = susceptibility-weighted imaging; TIA = transient ischemic attack; TOF = time-of-flight; $\mathrm{tPA}=$ tissue plasminogen activator. ation and management of patients in whom acute ischemic stroke is suspected. In addition to displaying anatomical structures, the latest neuroimaging techniques can elucidate the underlying hemodynamics and pathophysiology. The goals of comprehensive imaging in patients with acute stroke are to provide prompt accurate diagnosis, facilitate triage, expand treatment cohort, optimize individual outcome, and strategize secondary precautions. Logistically, the best-practice protocol at each institution varies and depends on available imaging modalities, physicians' preferences, intervention capabilities, and time constraints.

This review will briefly discuss the utility of comprehensive imaging in acute stroke. Patients who present with acute stroke symptoms fall into one of 3 broad categories: 1) candidates for IV tPA, 2) candidates for endovascular therapy, and 3) other settings. The following discussion is organized based on these 3 categories.

\section{Establishing the Diagnosis of Acute Ischemic Stroke}

\section{Ruling Out Intracranial Hemorrhage}

The initial step in the evaluation of patients with symptoms of acute stroke is to differentiate between hemorrhagic and ischemic stroke. Since intracranial hemorrhage is an absolute contraindication for reperfusion ther- 
apies, ${ }^{1,92,93}$ most stroke protocols begin with noncontrast head CT (NCHCT). NCHCT has been widely accepted as the standard method for the detection of acute intracranial hemorrhage since early reports describing its accuracy with early-generation CT scanners. ${ }^{88,167}$ However, its sensitivity and specificity in detecting intracranial hemorrhage have not been formally studied by comparing to actual pathological/histological specimens.

Although CT is the standard method, gradient T2*weighted MRI sequences (including gradient-recalled echo [GRE] and susceptibility-weighted imaging [SWI] sequences) are equally-if not more-sensitive for the detection of acute intracranial hemorrhage. ${ }^{56,105}$ The accuracy of MR imaging techniques in the detection of intracranial hemorrhage in acute stroke setting (within 6 hours) was reported as likely equivalent to NCHCT. ${ }^{56,105}$ Furthermore, T2*-weighted sequences have superior accuracy in the detection of small hemosiderin deposits from chronic microhemorrhages, ${ }^{98,105,124}$ which are often undetected on NCHCT due to insufficient signal contrast and limited spatial resolution. However, the clinical significance of microhemorrhages is uncertain and remains an area of intense investigation. While a meta-analysis of patients who received IV thrombolysis with a small number of chronic hemorrhages (fewer than 5) concluded that there is no significantly increased risk of hemorrhage, ${ }^{23,58}$ the outcome when numerous microhemorrhages (5 or more) are present has not been studied.

\section{Diagnosing Ischemic Stroke}

Early ischemic changes in NCHCT include loss of gray-white distinction, indistinct insular cortex and obscured basal ganglia, and hyperattenuated clot in the proximal vessels ${ }^{166,219}$ (Fig. 1). The hyperdense vessel sign is most specific but has low sensitivity. ${ }^{127}$ Abnormalities on NCHCT are present in $40 \%-50 \%$ of acute ischemic strokes. ${ }^{217,219}$ When obvious signs are present, NCHCT allows rapid diagnosis and correlation with presenting symptoms. However, acute ischemic changes are often subtle, with intra- and interobserver variability. ${ }^{68}$ Multiple classification systems based on imaging features have been developed to offer reliable, reproducible grading of the extent of ischemic changes on NCHCT. One of them is the Alberta Stroke Program Early CT Score (ASPECTS), a 10-point scoring system ${ }^{12}$ (Fig. 2; Table 1). Studies have shown that baseline ASPECTS correlates inversely with severity as assessed by the NIHSS within the first 3 hours of middle cerebral artery (MCA) stroke onset. ASPECTS of 7 or lower has been shown to predict poor functional outcome $(78 \%$ sensitivity and $96 \%$ specificity) and symptomatic hemorrhage (90\% sensitivity and $62 \%$ specificity) ${ }^{220}$ (Fig. 3).

Diffusion-weighted imaging (DWI) is approximately 4 to 5 times more sensitive in detecting acute stroke than $\mathrm{NCHCT}^{25,33,57,65,92,116,219,221}$ (Fig. 4). Its sensitivity in detecting ischemia is reported as $99 \%$ with a high specificity of $92 \% .9,11,25,33,92,103,123,139,145$ Within minutes of vessel occlusion, failure of the sodium potassium pump leads to an influx of water from the extracellular space to the intracellular space. Cytotoxic edema restricts diffusion of water molecules and appears as increased signal intensity on DWI. ${ }^{204}$ About $95 \%$ of hyperacute infarcts are positive on DWI. ${ }^{, 52,65,139}$ DWI can detect acute brain infarction within 1 to 2 hours, while NCHCT may be negative for the first 24 to 36 hours. ${ }^{165}$ DWI can distinguish acute from chronic ischemia, thereby delineating new lesions even when located in proximity to prior ischemic injury $y^{145}$ (Table 2). Obscure lesions indiscernible on CT scans, such as lacunar infarcts, particularly those located in the posterior fossa, are better visualized on DWI. ${ }^{135,154,197}$

Despite strong evidence supporting DWI as superior to NCHCT for confirming diagnosis of acute stroke within the first 24 hours, ${ }^{25}$ logistical issues limits its use in emergent setting. Most institutions find it challenging to obtain emergent MRI without delaying treatment.

Of note, restricted diffusion is not exclusively observed in acute ischemic stroke, but can also be seen in some nonischemic entities. These include seizure, encephalitis, abscesses, metabolic derangement (hypoglycemia), Creutzfeldt-Jakob disease, lymphoma, and mucinous adenocarcinoma metastases. ${ }^{194}$ Under the guidance of clinical presentation, these entities can be readily differentiated when studies are reviewed in combination with studies using other imaging modalities such as FLAIR. Occasionally, clinical differentiation of seizures from acute stroke may be difficult. Discerning DWI lesions confined to a major vascular territory, a distinctive feature of acute stroke lesions, may be helpful.

\section{Determining Eligibility for IV tPA}

There is strong evidence supporting the use of IV tPA
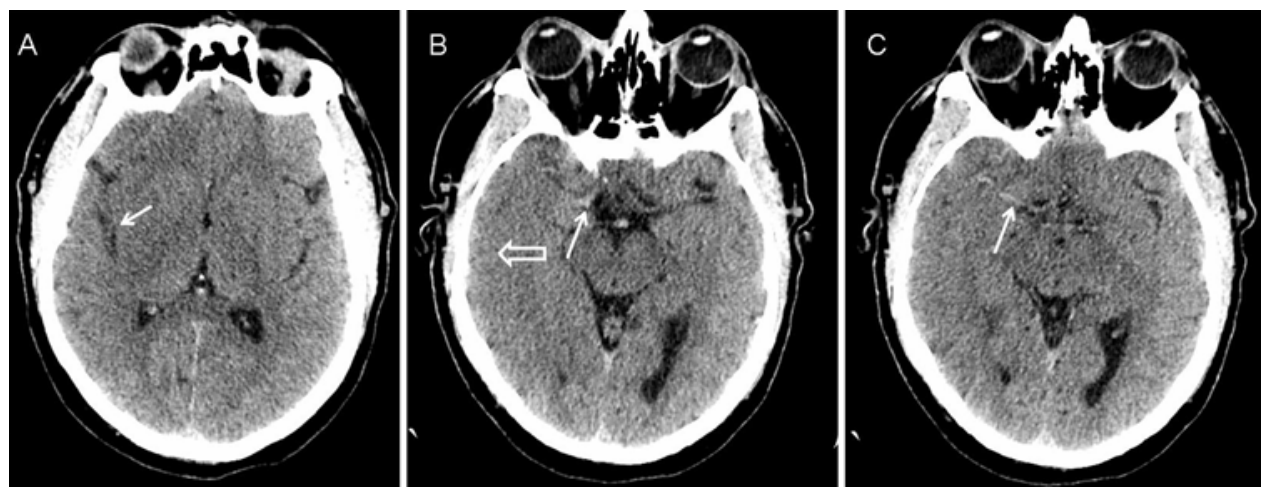

Fig. 1. Early ischemic changes on NCHCT. Axial NCHCT images demonstrating an indistinct right insular cortex (arrow, A) and obscured right basal ganglia, with loss of gray-white distinction (open arrow, B) and hyperdense right MCA (arrow, B and C). 

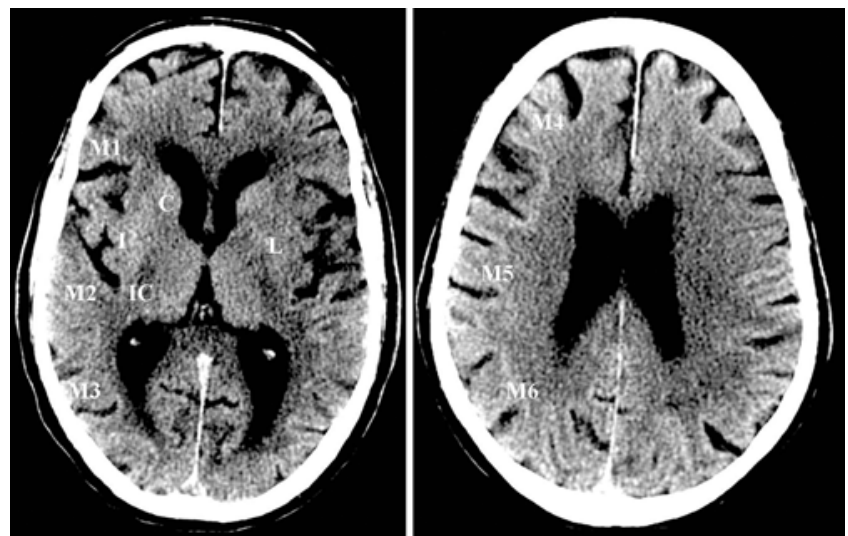

FIG. 2. Admission NCHCT of patient with ASPECTS 4, calculated at the level of the basal ganglia and at the supraganglionic level. In this scoring system, the MCA territory is divided into 10 regions: the caudate $(\mathrm{C})$, lentiform (L), internal capsule (IC), and 7 cortical regions (insular cortex [l], M1, M2, M3, M4, M5, and M6), based on data from Barber et al. ${ }^{12}$

as a recanalization therapy to improve clinical outcomes when patients present within the standard 0- to 3-hour time window ${ }^{1,73,155}$ and the extended 3- to 4.5-hour time window. ${ }^{21,72,125}$ There is also strong evidence supporting the timely use of imaging to exclude hemorrhage in stroke patients before initiating IV thrombolytic therapy. ${ }^{42,155}$ Admission NCHCT is recommended prior to thrombolysis, because intracranial hemorrhage is an absolute contraindication to IV thrombolysis. ${ }^{92,93}$ Ischemia involving more than one-third of the MCA territory on images obtained within the 0 - to 6 -hour window constitutes a relative contraindication to IV thrombolysis. ${ }^{73,122,218}$ Of note, there is disagreement regarding the significance of extensive ischemic signs on admission NCHCT. Early on, the European Cooperative Acute Stroke Studies (ECASS) reported poor outcome with increased incidence of hemorrhage following thrombolysis in patients with early extensive infarctions. ${ }^{218,219}$ However, the National Institute

\section{TABLE 1: Alberta Stroke Program Early CT Score*}

\begin{tabular}{cc}
\hline \multicolumn{1}{c}{ Region } & Value \\
\hline cortical & \\
M1 & -1 \\
M2 & -1 \\
M3 & -1 \\
M4 & -1 \\
M5 & -1 \\
M6 & -1 \\
insular cortex (I) & -1 \\
subcortical & \\
caudate (C) & -1 \\
lentiform nucleus (L) & -1 \\
internal capsule (IC) & -1 \\
\hline
\end{tabular}

* A normal CT scan has an ASPECTS of 10 points. One point is subtracted for ischemic changes in each region of the MCA territory. Data obtained from Barber et al. ${ }^{12}$
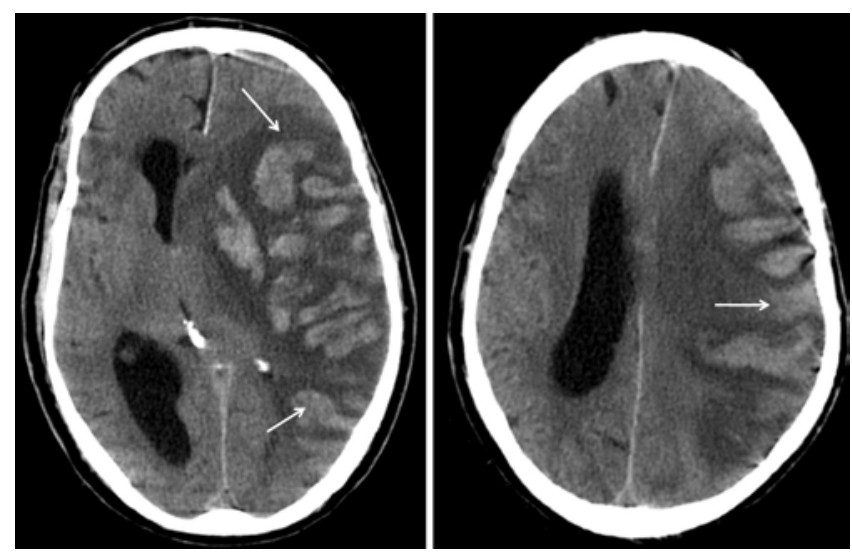

FIG. 3. Type PH2 hemorrhagic transformation. Axial NCHCT images obtained 14 hours after initial presentation in a patient with a left MCA infarct, demonstrating hemorrhagic transformation with confluent hematoma (arrows) and surrounding edema causing mass effect (leftto-right midline shift, subfalcine herniation, right lateral ventricle entrapment).

of Neurological Disorders and Stroke tPA Stroke Trial contested that early extensive infarctions were associated with symptom severity but not with adverse outcome after thrombolysis. ${ }^{166}$ Results from recent studies recommend withholding IV thrombolysis when more than onethird of the MCA territory is involved. ${ }^{196}$

\section{Identifying Candidates for Endovascular Revascularization}

\section{Detecting Large Artery Occlusion}

Imaging of the intracranial and extracranial vessels is needed to determine whether an embolus/thrombus is present and whether it is amenable to endovascular revascularization. The outcome after endovascular therapy depends on the location of the thrombus, with better recanalization rates associated with more proximal thrombus ${ }^{131,144,152,160,192}$ and poorer outcomes with occlusion of the carotid terminus. ${ }^{190,200}$

Digital subtraction angiography (DSA) is considered the reference standard for detection of vascular occlusions and stenoses. CTA has reportedly high sensitivity (97\%-100\%) and specificity (98\%-100\%) for detecting intracranial occlusions and stenoses. ${ }^{66,79,102,111,157,199,214,222}$ CTA also performs well in characterizing extracranial occlusions and stenoses, with high sensitivity (95\%-97\%) and specificity (90\%-99\%). ${ }^{112}$ In addition to evaluating the degree of stenosis in the extracranial arteries, CTA provides valuable information of the plaque-such as morphology and composition. ${ }^{224}$

Magnetic resonance angiography (MRA) can also be used to detect and localize the occlusion. ${ }^{15,42,93}$ Threedimensional (3D) time-of-flight (TOF) MRA is the standard MR technique for the examination of intracranial vessels. TOF MRA is, however, especially susceptible to motion artifact and tends to overestimate the degree of stenosis. ${ }^{89}$ Traditional contrast-enhanced MRA (boluschase MRA) is the MR technique of choice for the study 

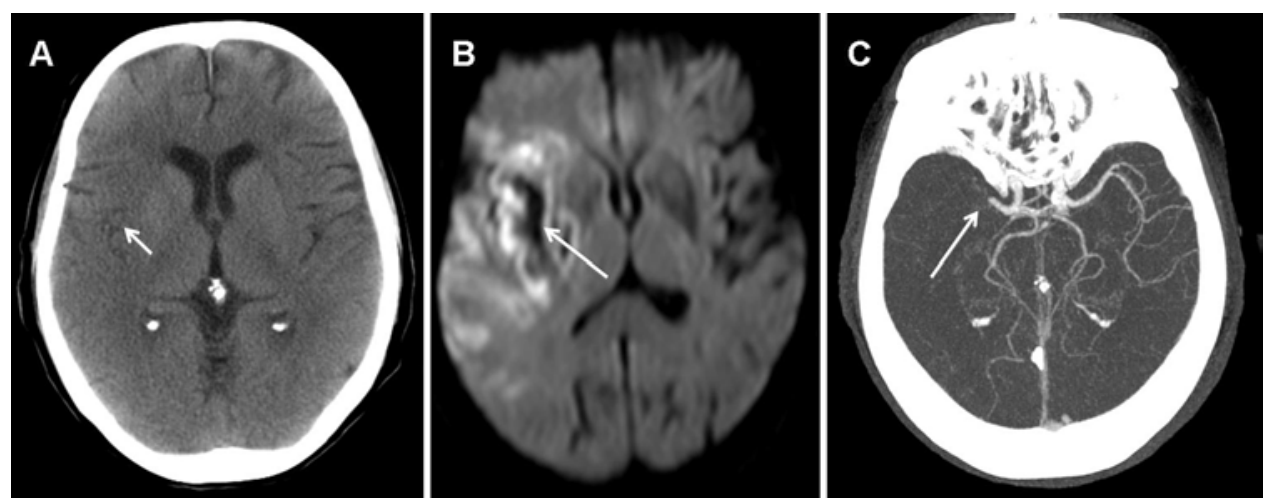

FIG. 4. Superior sensitivity of DWI in the detection of acute infarcts. A: Axial NCHCT image obtained at admission showing subtle obscuration of the right insular cortex (arrow). B: Axial DW image demonstrating hyperintense lesions in the right MCA territory-right lateral frontal cortex and right basal ganglia - consistent with acute infarction (arrow). The central hypodensities likely represent petechial hemorrhage. C: Axial CTA maximum intensity projection confirms occlusion of the $M_{1}$ segment of the right MCA (arrow).

of the extracranial arteries. It is relatively independent of flow dynamics and is less susceptible to motion artifacts (Fig. 5). Peak arterial enhancement is obtained by estimating the arrival of the contrast bolus. This technique is often limited by inaccurate timing of the bolus, which causes venous contamination..$^{133}$ Newer time-resolved contrast-enhanced MRA repeatedly acquires images of a volume during the passage of the contrast material. Delineation of arterial vasculature from venous vasculature is more accurate. ${ }^{114,133}$ Additionally, the dynamic acquisition allows visualization of complex flow patterns. ${ }^{114,133}$

The combined use of 3D TOF and contrast-enhanced MRA can improve diagnostic ability. ${ }^{203}$ However, CTA has been shown to be slightly superior to MRA for this purpose, typically for distal vascular lesions ${ }^{68,107}$ (Fig. 6).

\section{Assessing Viable Ischemic Brain Tissue}

Following an arterial occlusion, brain tissue that cannot sustain the sudden drop in perfusion rapidly undergoes infarction. The surrounding hypoperfused tissue that can autoregulate to sustain metabolic needs remains viable. ${ }^{77,225,226}$ The former is labeled "ischemic infarct core," and the injury to this tissue is irreversible. The latter is known as "ischemic penumbra." Differentiation of the ischemic core and ischemic penumbra relies on the tissue's ability to carry out vascular autoregulation. ${ }^{77,223,225,226}$ The penumbra is in danger of proceeding to infarction, but represents potentially salvageable tissue if recanalization is achieved quickly ${ }^{47,62,86,90}$ (Fig. 7). The evolution of the penumbra is a dynamic process and can be indirectly visualized by various advanced imaging techniques.

Perfusion-CT (PCT) can characterize cerebral perfusion by dynamically tracing an iodinated contrast bolus from its arrival to its departure.$^{50} \mathrm{PCT}$ allows quantitative assessment of cerebral blood flow (CBF), cerebral blood volume (CBV), and mean transit time (MTT). ${ }^{50}$ PCT delineation of the ischemic core and penumbra is typically based on the concept of cerebral vascular autoregulation. In the penumbra, where autoregulation is preserved, MTT is prolonged, but CBV is maintained. ${ }^{223}$ Quantitatively, a relative increase in MTT of $145 \%$ most accurately represents the penumbra. ${ }^{223}$ Within the ischemic core, where autoregulation is lost, there is a matched reduction in $\mathrm{CBF}$ and $\mathrm{CBV}$ with prolonged MTT. ${ }^{223}$ A prospective multicenter study reported an absolute $\mathrm{CBV}<2 \mathrm{~mL} / 100$ g optimally best delineated the ischemic core. ${ }^{106}$ However, more recent studies found relative $\mathrm{CBF}$ to be more predictive of the ischemic core. ${ }^{6,17-19,99,110,147,168,202}$

MRI delineation of the ischemic core and penumbra relies on DWI and perfusion-weighted imaging (PWI) techniques. ${ }^{67}$ Characterization of the ischemic core and penumbra on MRI is based on the assumption that the DWI abnormality reflects the ischemic core, whereas the PWI abnormality reflects the overall area of ischemia..$^{90}$ The PWI/DWI-mismatch is often thought to represent the ischemic penumbra ${ }^{36,64}$ (Table 3; Fig. 8). However, users should be cautious of the spontaneous resolution of

TABLE 2: Temporal changes of MRI findings in ischemic stroke*

\begin{tabular}{|c|c|c|c|c|c|c|}
\hline Time Frame & Etiology & DWI & ADC & $\mathrm{T} 1$ & $\mathrm{~T} 2$ & FLAIR \\
\hline acute (6-24 hrs) & vasogenic edema & hyperintense & hypointense & hypointense & hyperintense & hyperintense \\
\hline subacute (1-7 days) & $\begin{array}{l}\text { edema resolved; in- } \\
\text { farction, complete }\end{array}$ & hyperintense & isointense & hypointense & hyperintense & hyperintense \\
\hline chronic (>1 mo) & $\begin{array}{l}\text { edema resolved; } \\
\text { gliosis; encepha- } \\
\text { lomalacia }\end{array}$ & variable & hyperintense & hypointense & hyperintense & variable \\
\hline
\end{tabular}

* $\mathrm{T} 1=\mathrm{T} 1$-weighted sequences; $\mathrm{T} 2$ = T2-weighted sequences. 

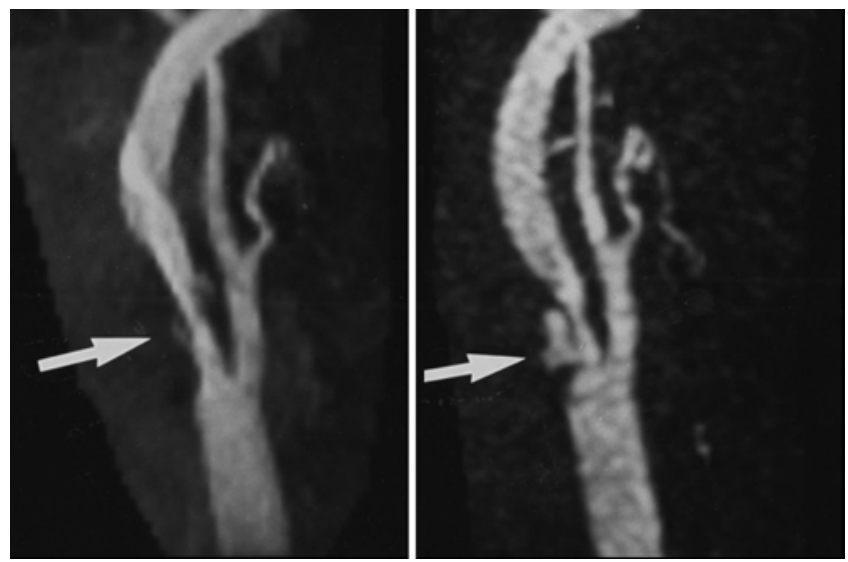

FIG. 5. MRA of the extracranial carotid artery. Left: 3D-TOF MR angiogram. This modality is more susceptible to motion artifact and overestimates the degree of stenosis at the internal carotid artery at the bifurcation of the common carotid artery (arrow). Right: Gadoliniumenhanced MR angiogram showing the true caliber of the right ICA bulb and also unmasking an ulceration (arrow) that could not be detected on the TOF MRA because of the absence of rapid flow within it.

some DWI hyperintense lesions ${ }^{119}$ (Fig. 9), and the inclusion of benign oligemia within the PWI abnormalities that are not at risk for infarction. ${ }^{104}$ The extent of mismatched tissue varies depending on the perfusion parameter selected and the threshold selected to represent the PWI abnormality. ${ }^{60,70,71,104,119,170}$ In a post hoc analysis of the DEFUSE trial, ${ }^{4}$ defining penumbra by using Tmax of 4-6 seconds provided the most accurate estimate of the penumbra. ${ }^{162}$ Other studies recommended using Tmax $>$ 6 seconds. ${ }^{120,150,162}$ There is no consensus on the optimal perfusion parameter for the definition of infarct core and penumbra. Further studies to standardize perfusion imaging are needed.

The clinical utility of penumbral imaging has not been proven. The utilization of penumbral imaging in the decision for mechanical embolectomy has generated mixed results in recent clinical trials..$^{107,207}$ Trials such as Diffusion-Weighted Imaging Evaluation For Understanding Stroke Evolution (DEFUSE), DEFUSE-2, and Echoplanar Imaging Thrombolysis Evaluation Trial (EPITHET) showed promising results by using a combination of diffusion and perfusion imaging as selection criteria for revascularization therapy beyond 3 hours..$^{4,41,121}$ However, the MR and Recanalization of Stroke Clots Using Embolectomy (MR RESCUE) trial, a multicenter, blinded randomized-controlled trial, failed to show benefits in using penumbra imaging, and was also unable to show superiority of endovascular mechanical thrombectomy over medical treatment. ${ }^{107}$ The Desmoteplase in Acute Ischemic Stroke-phase II (DIAS-II) trial used MR diffusion/perfusion mismatch and a perfusion-CT mismatch as selection criteria to administer IV desmoteplase in patients presenting up to 9 hours since symptom onset. ${ }^{71}$ This trial also failed to demonstrate superiority of treatment over placebo.

Further randomized-controlled trials are needed to support the accuracy and usefulness of perfusion imaging in the selection of patients for acute reperfusion therapy. One of the ongoing trials is the EXTEND trial, in which patients with mismatch on diffusion/perfusion-weighted MRI or PCT in the 4.5- to 9-hour time window are randomly assigned to receive IV tPA or placebo. ${ }^{140}$

\section{Assessing Cerebral Collateral Circulation}

Cerebral collateral circulation designates the alternate vascular pathways that allow ischemic brain tissue to receive its blood supply despite the occlusion of the primary supplying artery. Collateral vessels are divided into 1) primary collaterals at the circle of Willis and 2) secondary collaterals by recruitment of leptomeningeal vessels to perfuse adjacent cerebral and cerebellar territories in a retrograde fashion. ${ }^{128}$ Anatomical variation in the circle of Willis is common, ${ }^{128}$ and its appearance may change dynamically, from hypoplastic to ectatic, based on fluctuating demand. ${ }^{132}$ Collaterals have been shown to enhance recanalization and reperfusion, reduce the size of the final infarct core, slow ischemic lesion growth, decrease the risk of hemorrhagic transformation, and improve the outcome of IV thrombolytic therapy and endovascular revascularization. ${ }^{181,205}$ A poor pattern of collateral circulation has a high specificity for poor tissue and clinical outcome. ${ }^{10}$

Currently, there is no established standard imaging technique to quantify and qualify the extent of collateral circulation. The Technology Assessment Committees of the American Society of Interventional and Therapeutic
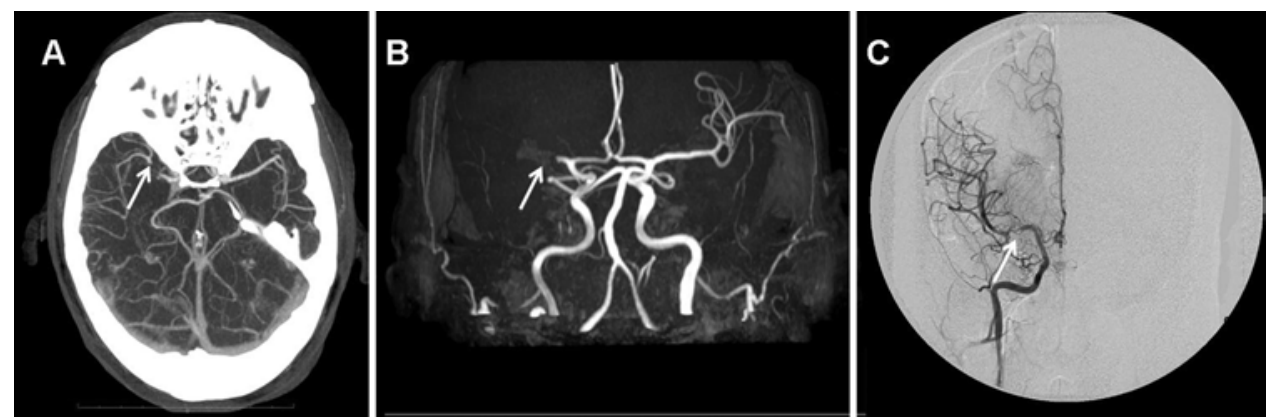

FIG. 6. Vascular occlusion detected by CTA, MR 3D-TOF, and DSA. A: CTA maximum intensity projection demonstrating severe stenosis in the $M_{1}$ segment of the right MCA (arrow). There is retrograde filling of the distal portions of the right MCA by collaterals. B: MR 3D-TOF image demonstrating overestimation of the stenosis and showing absence of antegrade flow in the right MCA distal to the stenosis. C: DS angiogram demonstrating a short segment of tight stenosis in the proximal right MCA (arrow) with collaterals. 
E. Tong et al.
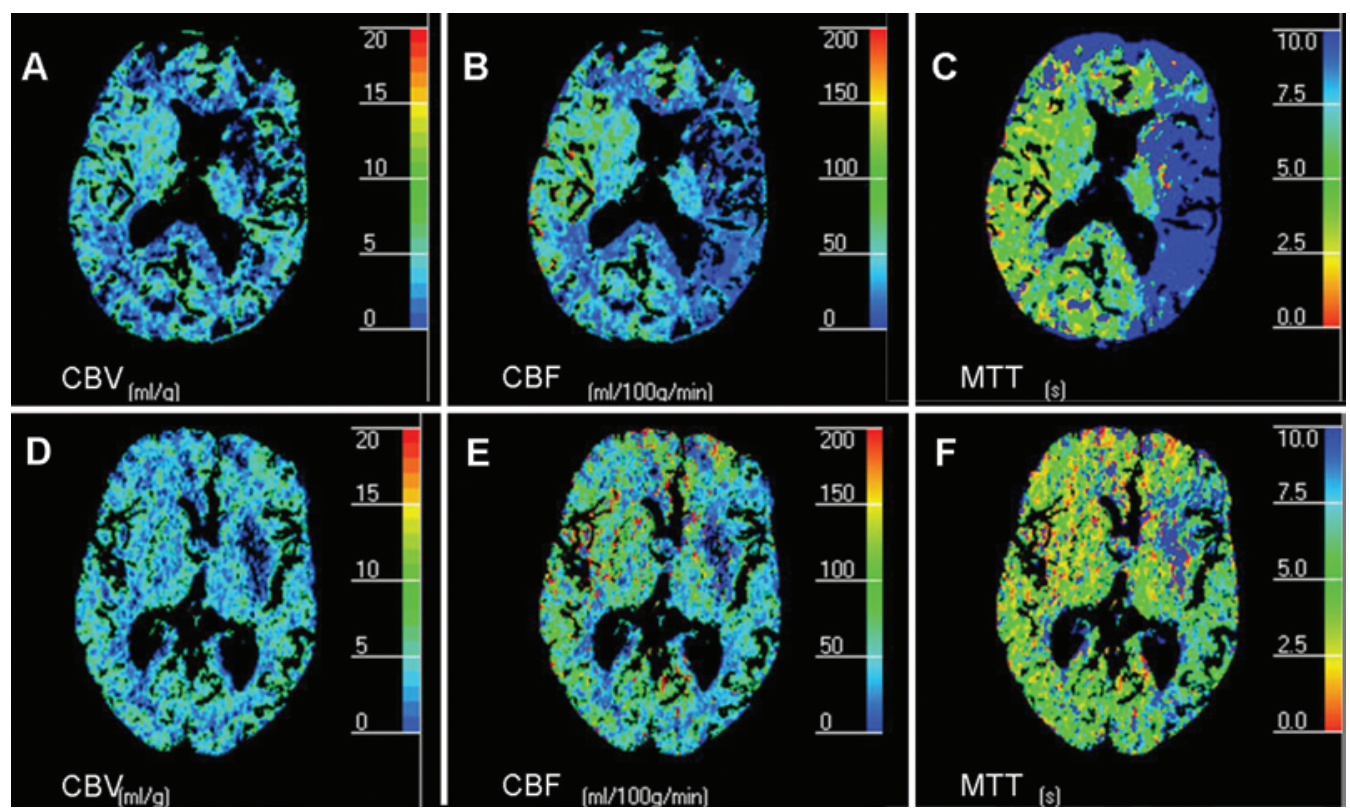

FIG. 7. PCT maps obtained in a patient with left MCA stroke before and after thrombectomy. A-C: Pretreatment images. The CBV map (A) shows decreased CBV in the left frontal lobe. The CBF map (B) shows decreased CBF in the left frontoparietal lobe. Regions with CBV $<2 \mathrm{ml} / 100 \mathrm{~g}$ represent infarct core. The MTT map (C) shows a large region of prolonged MTT in the left hemisphere, representing the penumbra. D-F: Images obtained after endovascular thrombectomy. The CBV (D), CBF (E), and MTT (F) maps show reduction of the lesion, suggesting salvaged ischemic tissue, with only a residual infarct (low CBV, low CBF, high MTT) in the left lenticular nucleus. $s=$ seconds.

Neuroradiology and the Society of Interventional Radiology recently proposed a standardized classification scheme for leptomeningeal collaterals ${ }^{78}$ (Table 4). Several imaging approaches have been explored, including DSA, ${ }^{8}$ $\mathrm{CTA},{ }^{148}$ arterial spin-labeling (ASL), ${ }^{34,215} \mathrm{PWI},{ }^{8,158}$ and PCT. 108

Primary and secondary collateral vessels can be directly characterized with conventional angiography utilizing DSA. Angiography illustrates collaterals in real time with good spatial and temporal resolution. ${ }^{129}$ Angiography also has the unique ability to isolate each major vascular territory by selective injection. ${ }^{130}$

CTA has been proposed as a surrogate for DSA in the assessment of collateral circulation. However, CTA only offers a snapshot of the cerebral vessels without dynamic information and can only provide an approximation of the maximum extent of collaterals. ${ }^{129}$ The dynamic nature of collaterals is better appreciated on PCT, which follows the dispersion of a contrast bolus by performing a repeated series of images at predefined slice locations.

Perfusion imaging techniques provide estimates of collateral flow through measurement of the contrast arrival delay, typically featuring prolonged time-to-peak (TTP) or mean transit time (MTT) with relative preserva-

TABLE 3: Perfusion-weighted imaging/diffusion-weighted imaging in acute ischemic stroke

\begin{tabular}{cl}
\hline Finding & \multicolumn{1}{c}{ Interpretation } \\
\hline$P W I>D W I$ & mismatched regions likely represent penumbra \\
$\mathrm{PWI}=\mathrm{DWI}$ & infarcted lesion, no penumbra \\
$\mathrm{PWI}<\mathrm{DWI}$ & early reperfusion of the ischemic tissue \\
\hline
\end{tabular}

tion of cerebral blood flow (CBF). ${ }^{129,130}$ ASL is a method for describing brain perfusion based on MRI without the need of a contrast medium. The blood in a region of interest is magnetically labeled. As the labeled blood flows, its paramagnetic effect alters the image intensity. ${ }^{32}$ ASL technique can be applied selectively to individual artery, thereby delineating the regions each vessel supplies. This technique can show collaterals, arising from one artery, supplementing another occluded or stenotic artery. ${ }^{34}$

\section{Determining Eligibility for Endovascular Revascularization}

Mechanical thrombectomy devices received FDA approval for use in patients presenting up to 8 hours after symptom onset because of early recanalization being associated with a 4- to 5-fold improvement in clinical outcome. ${ }^{177}$

Three imaging strategies for selecting patients for endovascular revascularization were proposed. In the first strategy, the patient proceeds to the angiography suite immediately after the initial NCHCT, thus minimizing the door-to-recanalization time. The patency of the vessels and collaterals are assessed by DSA. However, infarct volume can only be indirectly assessed by attention to flow, parenchymal blush, and arterial-to-venous transit times. The second strategy utilizes multimodal CT (NCHCT and CTA) to assess ischemic core and vascular patency (with optional PCT for penumbra assessment) for making decisions regarding endovascular therapy. The rationale for this approach is to limit catheterization studies to those patients with a vascular clot amenable to endovascular treatment. The third strategy uses multimodal MRI for information gathering, which includes DWI, the 


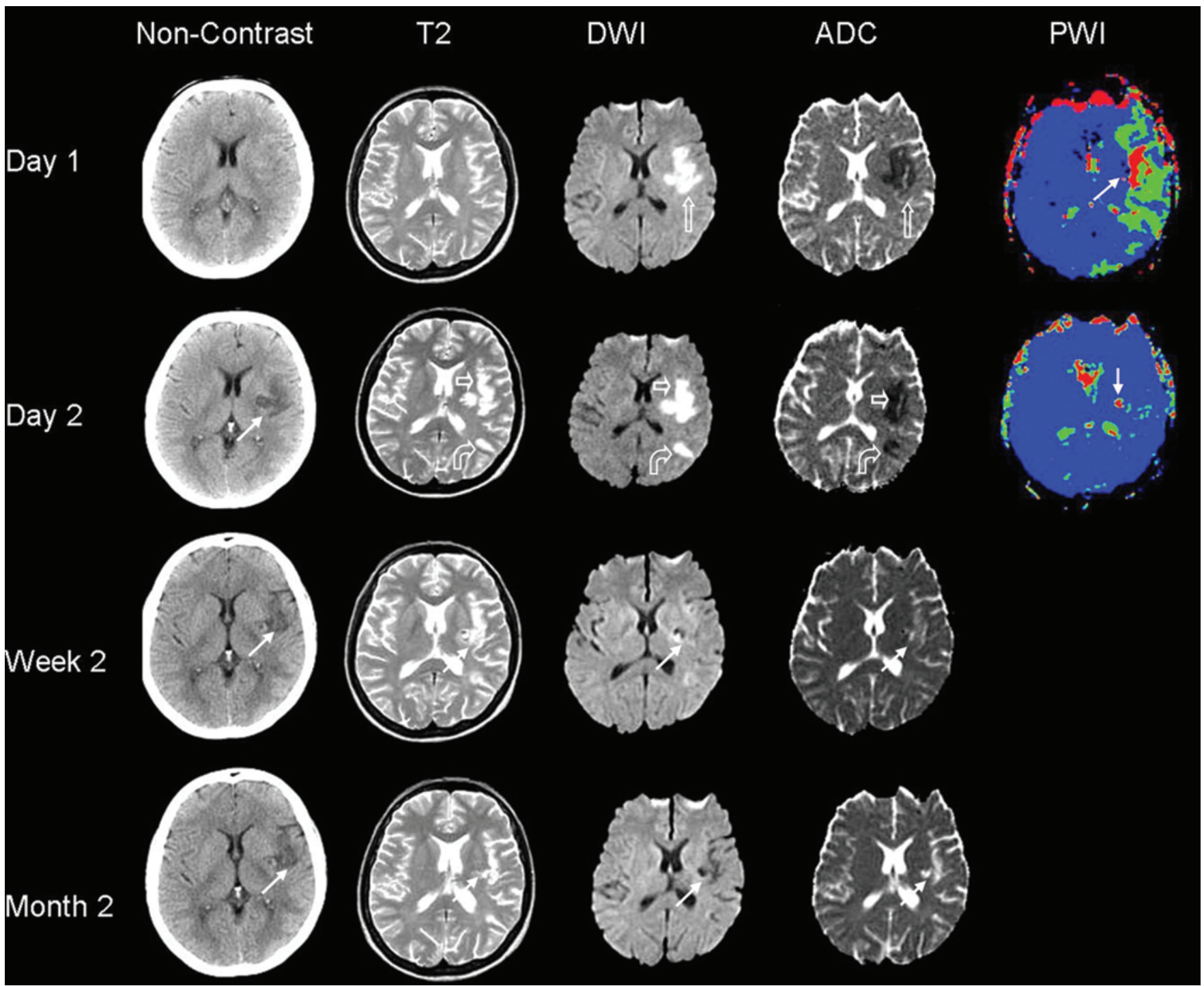

FIG. 8. Evolution of stroke on NCHCT and MRI. Day 1: NCHCT demonstrates obscure left insular cortex. No abnormal lesion is identified on T2-weighted imaging. DWI and ADC images show restricted diffusion in the left insular cortex and left lenticular nucleus, consistent with acute infarction (open arrow). PWI abnormalities in the left MCA territory. The PWI/DWI mismatch is thought to represent ischemic penumbra (arrow). Day 2: NCHCT demonstrates hypodense left lenticular nucleus and left insula (arrow), consistent with acute infarction. The corresponding lesion is identified on T2-weighted MRI and DWI (open arrow) with an additional hyperintense lesion in the left temporal cortex (open curve arrow). The abnormality on PWI (arrow) is mostly resolved. Week 2: Subacute infarct in the left lentiform nucleus (arrow). Month 2: The images show a chronic infarct in the left lentiform nucleus (arrow).

most accurate method, to assess the extent of the ischemic core. Several studies have demonstrated that the extra time required for MRI/DWI did not adversely affect the outcome. ${ }^{26,113,195}$ To date, there is no definitive evidence to favor one strategy over the other.

\section{Other Settings}

For the remaining patients not falling under the broad categories described above, imaging still plays a crucial role. This is a conglomerate group including those with wake-up strokes (in which patients awaken with neurological deficits), transient ischemic attack (TIA), and posterior fossa strokes.

\section{Wake-Up Stroke}

Currently, patients with unknown onset of symptoms, such as those who suffer wake-up stroke, are often denied treatment. Multimodal MRI (using DWI-PWI mismatch or DWI-FLAIR mismatch) or multimodal CT (NCHCT, CTA, and PCT) may be used to assess the "tissue clock."100,209,210 A recent study has shown that a DWIpositive lesion in a patient with a concomitant normal FLAIR image suggests that less than 3 hours has elapsed, with $>90 \%$ specificity and positive predictive value (Fig. 10). Therefore, if acute reperfusion therapy is considered, distinguishing a matched DWI-FLAIR lesion from a mismatched DWI-FLAIR lesion may be a plausible way to estimate the elapsed time since onset and identify patients 
E. Tong et al.
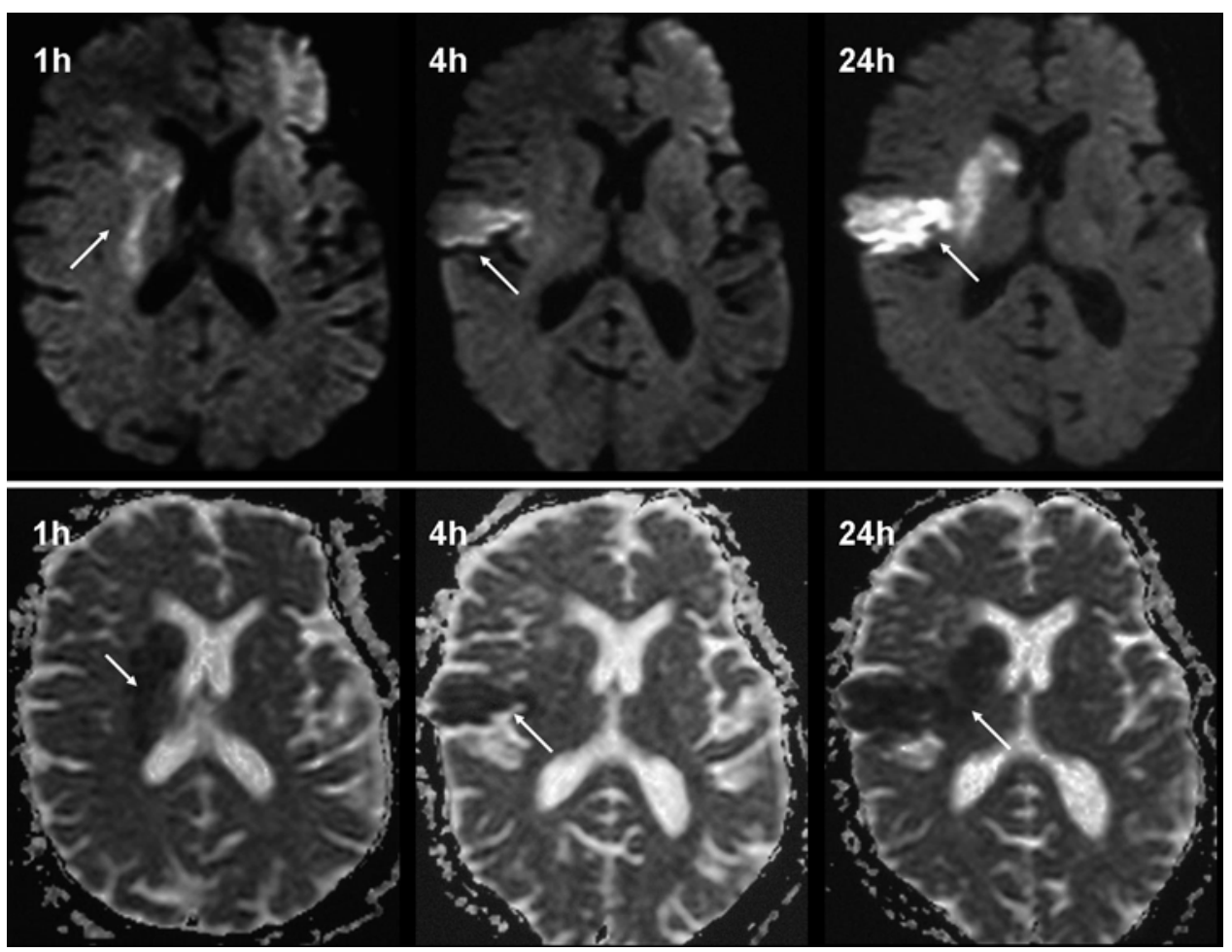

FIG. 9. Reversible DWI lesions. Axial DW (upper) and ADC (lower) images. The DW image obtained 1 hour (h) after presentation shows a hyperintense lesion in the right basal ganglia. The DW image obtained 4 hours after presentation shows a hyperintense lesion at the right inferolateral frontal lobe. The abnormality previously seen in the right basal ganglia has resolved. The DW image obtained 24 hours after presentation show the hyperintense lesion at the right inferior frontal lateral lobe and reappearance of the lesion in the right basal ganglia.

who are likely to benefit from thrombolysis. ${ }^{211}$ However, there is no prospective evidence supporting imaging selection for treatment in this patient population.

\section{Transient Ischemic Attacks}

Patients with TIAs are a very diverse group in terms of their symptoms, risk factors, prognosis, and future stroke risk. As the presenting symptoms can be diverse, imaging can potentially help to improve the accuracy of TIA diagnosis. DWI abnormalities are found in approximately $40 \%$ of patients with TIAs. ${ }^{37,139,176}$

After establishing the diagnosis of TIA, triage begins with identifying patients who require admission, which depends on their imminent stroke risk. Several scoring systems have been proposed to predict stroke risk in pa- tients with TIAs. ${ }^{38,95,96}$ The ABCD2 score is one of the more widely used systems. This score represents the summation of points associated with 5 clinical factors independently predictive of stroke risk-age, blood pressure, clinical features such as unilateral weakness or speech impairment, symptom duration, and the presence of diabetes $^{153}$ (Table 5). The ABCD2 score has been shown to accurately predict the risk of stroke at 2,7 , and 90 days following a TIA. ${ }^{153}$

Studies have shown imaging, MRI, or CT can further enhance the prediction of stroke risk..$^{38,48,172}$ Abnormalities on DWI are associated with a higher risk of additional vascular events. ${ }^{39}$ Other imaging features associated with stroke risk include occlusion of large cervicocerebral arteries, ${ }^{38,55,172}$ and embolic signals on transcranial Doppler sonography. ${ }^{126,146}$

TABLE 4: American Society of Interventional and Therapeutic Neuroradiology/Society of Interventional Radiology collateral flow grading system*

\begin{tabular}{cl}
\hline Score & Description \\
\hline 0 & no collaterals visible to the ischemic site \\
1 & slow collaterals to the periphery of the ischemic site, w/ persistence of some of the defect \\
2 & $\begin{array}{r}\text { rapid collaterals to the periphery of the ischemic site, w/ persistence of some of the defect, but only to a portion of } \\
\text { the ischemic territory }\end{array}$ \\
3 & collaterals w/ slow but complete angiographic blood flow of the ischemic bed occurring by the late venous phase \\
4 & complete \& rapid collateral blood flow to the vascular bed of the entire ischemic territory, by retrograde perfusion \\
\hline
\end{tabular}

* Data obtained from Higashida et al. ${ }^{78}$ 

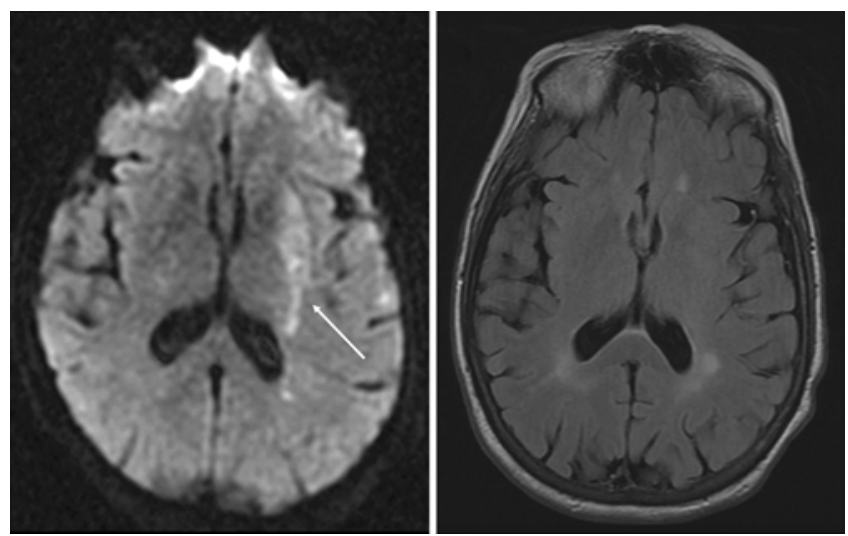

FIG. 10. Use of DWI-FLAIR mismatch to estimate the elapsed time since onset. Left: Axial DW image obtained in patient presenting with acute right-side weakness. There is restricted diffusion in the left basal ganglia, consistent with acute infarction. Right: Axial FLAIR image obtained in the same patient, showing no matching abnormality suggests an elapsed time of less than 3 hours.

Treatment of TIA is for secondary stroke prevention and is broadly divided into medical and/or surgical. The detailed recommendations for the treatment of TIA are beyond the scope of this review. (Please refer to the latest guidelines from the American Heart Association and American Stroke Association.) In brief, the current recommendations include antiplatelet therapy with rigorous lipid control. Surgical options include endarterectomy and carotid artery angioplasty with stent placement. ${ }^{2}$

DSA is the reference standard in the assessment of stenosis and in the decision for surgical intervention. ${ }^{14}$ Results from the North American Symptomatic Carotid Endarterectomy Trial (NASCET), the European Carotid Surgery Trial (ECST), and the Veteran Affairs trials ${ }^{175,180}$ recommend carotid endarterectomy or stenting in patients with symptomatic carotid stenosis of 70\%-99\% and with a life expectancy of at least 5 years. The NASCET method of determining the degree of carotid artery stenosis measures the most stenotic lumen diameter and compares it with the normal internal carotid artery lumen diameter distal to the stenosis. ${ }^{54}$ Other techniques, such as CTA or MRA of the intracranial and cervical arteries and duplex ultrasonography (DUS) of the cervical arteries are

TABLE 5: ABCD2 score to assess the risk of stroke after TIA*

\begin{tabular}{lc}
\hline \multicolumn{1}{c}{ Criterion } & Points \\
\hline age $\geq 60$ yrs & 1 \\
$\mathrm{SBP} \geq 140 \mathrm{~mm} \mathrm{Hg}$ or $\mathrm{DBP} \geq 90 \mathrm{~mm} \mathrm{Hg}$ & 1 \\
clinical features & \\
speech impairment & 1 \\
$\quad$ unilateral weakness & 2 \\
duration & \\
$10-59$ min & 1 \\
$\geq 60$ min & 2 \\
diabetes & 1 \\
\hline
\end{tabular}

* Data obtained from Naghavi et al..$^{153}$ DBP = diastolic blood pressure; $\mathrm{SBP}=$ systolic blood pressure. also used to identify stenosis. ${ }^{49}$ Overall, these noninvasive techniques have shown good agreement with DSA in approximately $90 \%$ of cases. ${ }^{20,138,174}$ Concordant results of two noninvasive techniques (DUS, CTA, and/or MRA) can be used to determine revascularization procedures, thus circumventing catheterization risks. ${ }^{94,156}$

Assessment of atherosclerosis, an important risk factor for cerebrovascular ischemic events, has recently shifted from lumen measurement to the evaluation of the plaque structure and composition. ${ }^{153,182,189,198}$ Several features have been shown to increase the risk of cerebrovascular events, including plaque ulceration, intraplaque hemorrhage, and a ruptured or fissured fibrous cap. Ulceration within plaques $^{14,51}$ is best imaged on CTA. ${ }^{183,184,213}$ Intraplaque hemorrhage is best evaluated with MRI, which can determine the chronicity of the hemorrhage by distinguishing signal intensities on T1-weighted, T2-weighted, proton density weighted, and TOF images. ${ }^{29,30,35}$ Protective features such as fibrous cap are best assessed on MRI;43,75,149 TOF MRI can detect ruptured or fissured fibrous caps. ${ }^{75}$

Plaque composition can be evaluated on ultrasound, CT, or MRI. CT measures the density in Hounsfield units. The Gray-Weale classification is commonly used to evaluate the composition on ultrasonography, ${ }^{61}$ based on the echogenicity of the plaque. This classification has been shown to correspond to the fatty, mixed, and calcified plaques on CT. ${ }^{188}$ Plaque volume is easily calculated using CTA-based software. Plaque neovascularization, a hallmark of advanced atherosclerotic lesions, ${ }^{13}$ can be evaluated on contrast-enhanced ultrasonography, ${ }_{118,206,228}$ CT, ${ }^{81,179,185-187}$ and dynamic contrast-enhanced MRI. ${ }^{173}$

\section{Posterior Fossa Stroke}

There are a few imaging aspects specific to posterior fossa infarction due to its unique location and dire prognosis. Poor image quality secondary to beam-hardening artifacts limits the sensitivity of NCHCT and PCT to posterior fossa ischemia. ${ }^{87}$ DWI is the optimal imaging technique to assess the presence of ischemia in the posterior fossa. ${ }^{151}$ DWI can also assess the degree of brainstem infarction before proceeding with endovascular treatment.

CTA and DSA are the preferred imaging techniques to assess for basilar artery thrombosis. ${ }^{22}$ In one study ${ }^{66}$ the detection of basilar artery occlusion on CTA was equivalent to detection on DSA, with accurate location of the thrombosis, and equivalent capability of detecting stenosis $>50 \%$. The extent of the thrombosis could be more precisely measured on CTA. ${ }^{66}$ However, CTA failed to detect occlusion in the vertebral artery in about onehalf of cases. ${ }^{66}$ The differentiation between high-grade stenosis and hypoplasia on CTA was most disparate from DSA. ${ }^{66}$ MRA is an acceptable alternative.

Leniency regarding the treatment time window is often granted in cases of basilar occlusion due to its dismal prognosis. $^{2}$

\section{Stroke Complications}

Malignant edema and hemorrhagic transformation are the most feared complications of ischemic stroke. Hemorrhagic transformation, a common complication 
of severe stroke (Fig. 3), is likely caused by a synergistic combination of reperfusion ${ }^{150,191}$ and a disrupted blood brain barrier. ${ }^{191}$ The clinical presentation of hemorrhagic transformation is widely variable, ranging from subtle neurological findings to sudden rapid decline and death.

The spectrum of imaging findings is wide, ranging from petechial hemorrhage to confluent hemorrhage. Studies on thrombolytic treatment have categorized the findings into 4 groups: HI1, characterized by small petechiae along the margins of the infarct; HI2, characterized by more confluent petechiae within the infarcted area; PH1, characterized by hematoma involving $30 \%$ of the infarcted area or less, with slight mass effect; and $\mathrm{PH} 2$, characterized by dense hematoma involving more than $30 \%$ of the infarcted area, with substantial mass effect, or any hemorrhagic lesion outside the infarcted area. ${ }^{16,171,227}$ HI1 and HI2, often asymptomatic, occur more frequently than the more symptomatic PH2. ${ }^{6,69,97,134}$ Hemorrhagic transformation can occur in untreated patients, with a mildly increased incidence in patients receiving antithrombotic treatment ${ }^{16,97,134}$ and a significantly higher incidence after thrombolysis. . $^{16,97,134}$

Different risk factors for hemorrhagic transformation have been identified: stroke severity, ${ }^{83,84}$ age, ${ }^{161}$ hyperglycemia/diabetes,$^{84}$ and cardioembolic stroke. ${ }^{5,31,83,164,178}$ Radiographic risk factors include large infarct are ${ }^{83,84,136,161,212}$ and early ischemic signs at the first NCHCT scan. ${ }^{24,82,178,212}$ It has been proposed that the incidence of hemorrhagic transformation depends on the underlying etiology. ${ }^{53,208}$ Specifically, cardioembolic stroke is widely accepted as a risk factor. $5,31,59,83,137,164,178$ Some have postulated that the softer consistency of the embolus yields higher rates of recanalization, which subsequently leads to hemorrhagic transformation. ${ }^{109}$ Others have observed that cardioembolic strokes frequently cause large-vessel occlusion, resulting in large infarcted area, which in turn is a risk factor for hemorrhagic transformation. ${ }^{137,208}$

Malignant edema, which is associated with a 40\%$80 \%$ risk of death ${ }^{74,101}$ (Fig. 11), occurs in $10 \%-15 \%$ of all MCA territory ischemic strokes. ${ }^{76,181}$ A "T occlusion" of the distal internal carotid artery is frequently associated with malignant edema..$^{91,117}$ Solitary infarction from MCA branch occlusions typically do not result in swelling with clinically significant mass effect. ${ }^{74}$ Additional vascular territory infarctions, an incomplete circle of Willis, and poor collateral circulation are additional risk factors for the development of malignant edema. ${ }^{27,91}$ There is no reliable way to predict the course of brain swelling.

NCHCT is the follow-up imaging modality of choice for patients with cerebral infarcts with swelling. The degree of midline shift on NCHCT is the most commonly used benchmark for monitoring deterioration. 28,44,46,141,143,216 NCHCT findings that predict malignant edema and poor prognosis include frank hypodensity on NCHCT within the first 6 hours and involvement of one-third of the MCA territory or more. ${ }^{101,115,117,142}$ The presence of a dense MCA $\operatorname{sign}^{142}$ or midline shift of $5 \mathrm{~mm}$ or more within the first 2 days $^{45}$ are also associated with neurological deterioration and early mortality. Blood-brain barrier permeability measurement on admission PCT have been shown to be highly sensitive in predicting malignant edema and
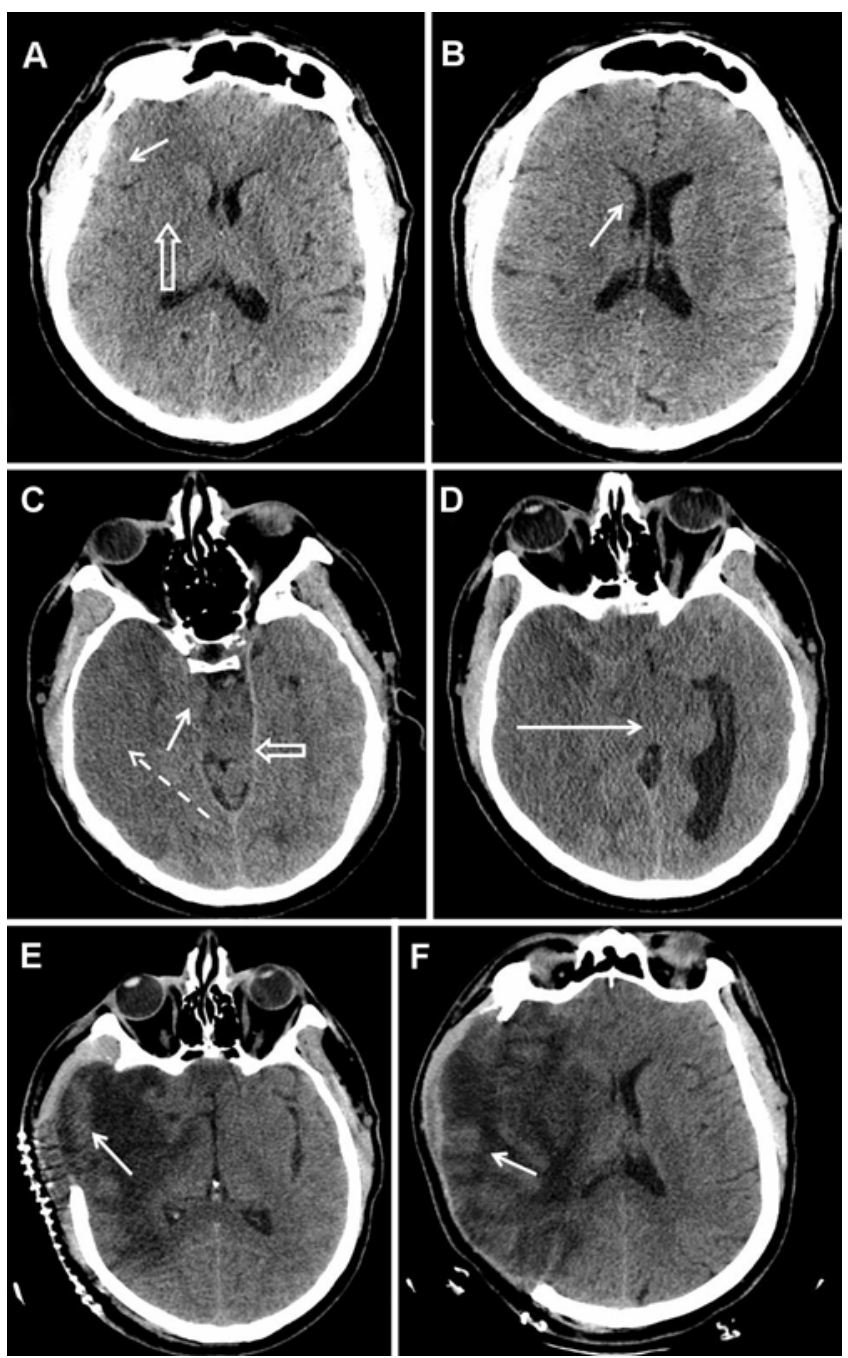

FIG. 11. Malignant edema in MCA stroke. A and B: Axial NCHCT images obtained at admission showing subtle obscuration of the right lentiform nucleus (open arrow, A) and loss of gray-white differentiation in the right frontal lobe (white arrow, $\mathrm{A}$ and $\mathrm{B}$ ), consistent with right MCA territory infarct. C and D: Axial NCHCT images obtained on Day 2 showing increased edema (broken arrow, C), causing right transtentorial uncal herniation (short white arrow, C), basal cistern effacement (open arrow, C), and leftward midline shift (white arrow, D). E and F: Axial NCHCT images obtained on Day 4, after right hemicraniectomy, demonstrating worsening edema despite surgical decompression with herniation of right frontal and parietal lobes through the craniectomy defect (white arrow, E and F).

hemorrhagic transformation (100\% sensitivity and $79 \%$ specificity). ${ }^{80}$

Measurement of DWI volume has been studied as a method of predicting neurological deterioration from cerebral edema. A DWI volume of more than than 80 $\mathrm{ml}$ within 6 hours of stroke onset is predictive of a rapid fulminant course. ${ }^{163}$ Results from PWI are inconsistent. ${ }^{10}$ Transcranial Doppler sonography, a noninvasive method for monitoring intracranial pressure, has been used for the detection of cerebral herniation and for therapy decision. High pulsatility indices correlated with increased midline shift and poor outcome., ${ }^{7,85}$ Near-infrared spectroscopy remains an investigational modality for nonin- 
vasively obtaining information on intracranial oxygenation in patients with infarctions and swelling. ${ }^{40}$

\section{Conclusions}

Neuroimaging has become a crucial component in acute stroke care. While capitalizing on the latest treatment options and expanding upon the "time is brain" doctrine, the ultimate goal of neuroimaging is to maximize the number of patients treated and improve the outcome of one the most costly and morbid diseases. Definitive validation of various aspects of stroke imaging awaits more research and further studies.

\section{Disclosure}

Dr. Wintermark reports receiving funding from GE Healthcare and Philips Healthcare and having a consultant relationship with Biogen Idec.

Author contributions to the study and manuscript preparation include the following. Conception and design: Wintermark, Tong. Acquisition of data: Fiebach. Drafting the article: all authors. Critically revising the article: all authors. Reviewed submitted version of manuscript: all authors. Approved the final version of the manuscript on behalf of all authors: Wintermark. Study supervision: Wintermark.

\section{References}

1. Adams HP Jr, Brott TG, Furlan AJ, Gomez CR, Grotta J, Helgason CM, et al: Guidelines for thrombolytic therapy for acute stroke: a supplement to the guidelines for the management of patients with acute ischemic stroke. A statement for healthcare professionals from a Special Writing Group of the Stroke Council, American Heart Association. Circulation 94:1167-1174, 1996

2. Adams HP Jr, del Zoppo G, Alberts MJ, Bhatt DL, Brass L, Furlan A, et al: Guidelines for the early management of adults with ischemic stroke: a guideline from the American Heart Association/American Stroke Association Stroke Council, Clinical Cardiology Council, Cardiovascular Radiology and Intervention Council, and the Atherosclerotic Peripheral Vascular Disease and Quality of Care Outcomes in Research Interdisciplinary Working Groups. Circulation 115:e478-e534, 2007

3. Adeoye O, Hornung R, Khatri P, Kleindorfer D: Recombinant tissue-type plasminogen activator use for ischemic stroke in the United States: a doubling of treatment rates over the course of 5 years. Stroke 42:1952-1955, 2011

4. Albers GW, Thijs VN, Wechsler L, Kemp S, Schlaug G, Skalabrin E, et al: Magnetic resonance imaging profiles predict clinical response to early reperfusion: the diffusion and perfusion imaging evaluation for understanding stroke evolution (DEFUSE) study. Ann Neurol 60:508-517, 2006

5. Alexandrov AV, Black SE, Ehrlich LE, Caldwell CB, Norris JW: Predictors of hemorrhagic transformation occurring spontaneously and on anticoagulants in patients with acute ischemic stroke. Stroke 28:1198-1202, 1997

6. Arakawa S, Wright PM, Koga M, Phan TG, Reutens DC, Lim I, et al: Ischemic thresholds for gray and white matter: a diffusion and perfusion magnetic resonance study. Stroke 37:1211-1216, 2006

7. Asil T, Uzunca I, Utku U, Berberoglu U: Monitoring of increased intracranial pressure resulting from cerebral edema with transcranial Doppler sonography in patients with middle cerebral artery infarction. J Ultrasound Med 22:1049-1053, 2003

8. Awad I, Little JR, Modic MT, Furlan AJ: Intravenous digital subtraction angiography: an index of collateral cerebral blood flow in internal carotid artery occlusion. Stroke 13:469-472, 1982

9. Ay H, Buonanno FS, Rordorf G, Schaefer PW, Schwamm LH, Wu O, et al: Normal diffusion-weighted MRI during strokelike deficits. Neurology 52:1784-1792, 1999

10. Bang OY, Saver JL, Kim SJ, Kim GM, Chung CS, Ovbiagele $\mathrm{B}$, et al: Collateral flow predicts response to endovascular therapy for acute ischemic stroke. Stroke 42:693-699, 2011

11. Barber PA, Darby DG, Desmond PM, Gerraty RP, Yang Q, $\mathrm{Li} \mathrm{T}$, et al: Identification of major ischemic change. Diffusion-weighted imaging versus computed tomography. Stroke 30:2059-2065, 1999

12. Barber PA, Demchuk AM, Zhang J, Buchan AM: Validity and reliability of a quantitative computed tomography score in predicting outcome of hyperacute stroke before thrombolytic therapy. ASPECTS Study Group. Alberta Stroke Programme Early CT Score. Lancet 355:1670-1674, 2000 (Erratum in Lancet 355:2170, 2000)

13. Barger AC, Beeuwkes R III, Lainey LL, Silverman KJ: Hypothesis: vasa vasorum and neovascularization of human coronary arteries. A possible role in the pathophysiology of atherosclerosis. N Engl J Med 310:175-177, 1984

14. Barnett HJ, Taylor DW, Eliasziw M, Fox AJ, Ferguson GG, Haynes RB, et al: Benefit of carotid endarterectomy in patients with symptomatic moderate or severe stenosis. N Engl J Med 339:1415-1425, 1998

15. Bash S, Villablanca JP, Jahan R, Duckwiler G, Tillis M, Kidwell C, et al: Intracranial vascular stenosis and occlusive disease: evaluation with CT angiography, MR angiography, and digital subtraction angiography. AJNR Am J Neuroradiol 26:1012-1021, 2005

16. Berger C, Fiorelli M, Steiner T, Schäbitz WR, Bozzao L, Bluhmki E, et al: Hemorrhagic transformation of ischemic brain tissue: asymptomatic or symptomatic? Stroke 32:13301335,2001

17. Bivard A, Levi C, Spratt N, Parsons M: Perfusion CT in acute stroke: a comprehensive analysis of infarct and penumbra. Radiology 267:543-550, 2013

18. Bivard A, McElduff P, Spratt N, Levi C, Parsons M: Defining the extent of irreversible brain ischemia using perfusion computed tomography. Cerebrovasc Dis 31:238-245, 2011

19. Bivard A, Spratt N, Levi C, Parsons M: Perfusion computer tomography: imaging and clinical validation in acute ischaemic stroke. Brain 134:3408-3416, 2011

20. Blakeley DD, Oddone EZ, Hasselblad V, Simel DL, Matchar DB: Noninvasive carotid artery testing. A meta-analytic review. Ann Intern Med 122:360-367, 1995

21. Bluhmki E, Chamorro A, Dávalos A, Machnig T, Sauce C, Wahlgren N, et al: Stroke treatment with alteplase given 3.0$4.5 \mathrm{~h}$ after onset of acute ischaemic stroke (ECASS III): additional outcomes and subgroup analysis of a randomised controlled trial. Lancet Neurol 8:1095-1102, 2009

22. Bonatti G, Ferro F, Haglmüller T, Pernter P, Naibo L: Basilar artery thrombosis: imaging and endovascular therapy. Radiol Med (Torino) 115:1219-1233, 2010

23. Boulanger JM, Coutts SB, Eliasziw M, Gagnon AJ, Simon JE, Subramaniam S, et al: Cerebral microhemorrhages predict new disabling or fatal strokes in patients with acute ischemic stroke or transient ischemic attack. Stroke 37:911-914, 2006

24. Bozzao L, Angeloni U, Bastianello S, Fantozzi LM, Pierallini A, Fieschi C: Early angiographic and CT findings in patients with hemorrhagic infarction in the distribution of the middle cerebral artery. AJNR Am J Neuroradiol 12:1115-1121, 1991

25. Brazzelli M, Sandercock PA, Chappell FM, Celani MG, Righetti E, Arestis N, et al: Magnetic resonance imaging versus computed tomography for detection of acute vascular lesions in patients presenting with stroke symptoms. Cochrane Database Syst Rev (4):CD007424, 2009 


\section{E. Tong et al.}

26. Breuer L, Schellinger PD, Huttner HB, Halwachs R, Engelhorn T, Doerfler A, et al: Feasibility and safety of magnetic resonance imaging-based thrombolysis in patients with stroke on awakening: initial single-centre experience. Int J Stroke 5:68-73, 2010

27. Brozici M, van der Zwan A, Hillen B: Anatomy and functionality of leptomeningeal anastomoses: a review. Stroke 34: 2750-2762, 2003

28. Burghaus L, Liu WC, Dohmen C, Bosche B, Haupt WF: Evoked potentials in acute ischemic stroke within the first 24 h: possible predictor of a malignant course. Neurocrit Care 9: 13-16, 2008

29. Cappendijk VC, Cleutjens KB, Heeneman S, Schurink GW, Welten RJ, Kessels AG, et al: In vivo detection of hemorrhage in human atherosclerotic plaques with magnetic resonance imaging. J Magn Reson Imaging 20:105-110, 2004

30. Cappendijk VC, Cleutjens KB, Kessels AG, Heeneman S, Schurink GW, Welten RJ, et al: Assessment of human atherosclerotic carotid plaque components with multisequence MR imaging: initial experience. Radiology 234:487-492, 2005

31. Castellanos M, Leira R, Serena J, Pumar JM, Lizasoain I, Castillo J, et al: Plasma metalloproteinase-9 concentration predicts hemorrhagic transformation in acute ischemic stroke. Stroke 34:40-46, 2003

32. Chalela JA, Alsop DC, Gonzalez-Atavales JB, Maldjian JA, Kasner SE, Detre JA: Magnetic resonance perfusion imaging in acute ischemic stroke using continuous arterial spin labeling. Stroke 31:680-687, 2000

33. Chalela JA, Kidwell CS, Nentwich LM, Luby M, Butman JA, Demchuk AM, et al: Magnetic resonance imaging and computed tomography in emergency assessment of patients with suspected acute stroke: a prospective comparison. Lancet 369: 293-298, 2007

34. Chng SM, Petersen ET, Zimine I, Sitoh YY, Lim CC, Golay X: Territorial arterial spin labeling in the assessment of collateral circulation: comparison with digital subtraction angiography. Stroke 39:3248-3254, 2008

35. Chu B, Kampschulte A, Ferguson MS, Kerwin WS, Yarnykh VL, O'Brien KD, et al: Hemorrhage in the atherosclerotic carotid plaque: a high-resolution MRI study. Stroke 35:10791084, 2004

36. Copen WA, Rezai Gharai L, Barak ER, Schwamm LH, Wu O, Kamalian S, et al: Existence of the diffusion-perfusion mismatch within 24 hours after onset of acute stroke: dependence on proximal arterial occlusion. Radiology 250:878-886, 2009

37. Coutts SB, Hill MD, Simon JE, Sohn CH, Scott JN, Demchuk AM: Silent ischemia in minor stroke and TIA patients identified on MR imaging. Neurology 65:513-517, 2005

38. Coutts SB, Simon JE, Eliasziw M, Sohn CH, Hill MD, Barber PA, et al: Triaging transient ischemic attack and minor stroke patients using acute magnetic resonance imaging. Ann Neurol 57:848-854, 2005

39. Cucchiara BL, Messe SR, Taylor RA, Pacelli J, Maus D, Shah $\mathrm{Q}$, et al: Is the ABCD score useful for risk stratification of patients with acute transient ischemic attack? Stroke 37:17101714,2006

40. Damian MS, Schlosser R: Bilateral near infrared spectroscopy in space-occupying middle cerebral artery stroke. Neurocrit Care 6:165-173, 2007

41. Davis SM, Donnan GA, Parsons MW, Levi C, Butcher KS, Peeters A, et al: Effects of alteplase beyond $3 \mathrm{~h}$ after stroke in the Echoplanar Imaging Thrombolytic Evaluation Trial (EPITHET): a placebo-controlled randomised trial. Lancet Neurol 7:299-309, 2008

42. DeLaPaz RL, Wippold FJ II, Cornelius RS, Amin-Hanjani S, Angtuaco EJ, Broderick DF, et al: ACR Appropriateness Criteria $^{\circledR}$ on cerebrovascular disease. J Am Coll Radiol 8:532538,2011
43. Demarco JK, Ota H, Underhill HR, Zhu DC, Reeves MJ, Potchen MJ, et al: MR carotid plaque imaging and contrastenhanced MR angiography identifies lesions associated with recent ipsilateral thromboembolic symptoms: an in vivo study at 3T. AJNR Am J Neuroradiol 31:1395-1402, 2010

44. Diringer MN, Scalfani MT, Zazulia AR, Videen TO, Dhar R: Cerebral hemodynamic and metabolic effects of equi-osmolar doses mannitol and $23.4 \%$ saline in patients with edema following large ischemic stroke. Neurocrit Care 14:11-17, 2011

45. Dohmen C, Bosche B, Graf R, Staub F, Kracht L, Sobesky J, et al: Prediction of malignant course in MCA infarction by PET and microdialysis. Stroke 34:2152-2158, 2003

46. Dohmen C, Galldiks N, Bosche B, Kracht L, Graf R: The severity of ischemia determines and predicts malignant brain edema in patients with large middle cerebral artery infarction. Cerebrovasc Dis 33:1-7, 2012

47. Donnan GA, Baron JC, Ma H, Davis SM: Penumbral selection of patients for trials of acute stroke therapy. Lancet Neurol 8:261-269, 2009

48. Douglas VC, Johnston CM, Elkins J, Sidney S, Gress DR, Johnston SC: Head computed tomography findings predict short-term stroke risk after transient ischemic attack. Stroke 34:2894-2898, 2003

49. Easton JD, Saver JL, Albers GW, Alberts MJ, Chaturvedi S, Feldmann E, et al: Definition and evaluation of transient ischemic attack: a scientific statement for healthcare professionals from the American Heart Association/American Stroke Association Stroke Council; Council on Cardiovascular Surgery and Anesthesia; Council on Cardiovascular Radiology and Intervention; Council on Cardiovascular Nursing; and the Interdisciplinary Council on Peripheral Vascular Disease. Stroke 40:2276-2293, 2009

50. Eastwood JD, Lev MH, Provenzale JM: Perfusion CT with iodinated contrast material. AJR Am J Roentgenol 180:3-12, 2003

51. Eliasziw M, Streifler JY, Fox AJ, Hachinski VC, Ferguson GG, Barnett HJ: Significance of plaque ulceration in symptomatic patients with high-grade carotid stenosis. Stroke 25:304-308, 1994

52. Engelter ST, Wetzel SG, Bonati LH, Fluri F, Lyrer PA: The clinical significance of diffusion-weighted MR imaging in stroke and TIA patients. Swiss Med Wkly 138:729-740, 2008

53. England TJ, Bath PM, Sare GM, Geeganage C, Moulin T, O'Neill D, et al: Asymptomatic hemorrhagic transformation of infarction and its relationship with functional outcome and stroke subtype: assessment from the Tinzaparin in Acute Ischaemic Stroke Trial. Stroke 41:2834-2839, 2010

54. European Carotid Surgery Trialists' Collaborative Group: Randomised trial of endarterectomy for recently symptomatic carotid stenosis: final results of the MRC European Carotid Surgery Trial (ECST). Lancet 351:1379-1387, 1998

55. Fairhead JF, Mehta Z, Rothwell PM: Population-based study of delays in carotid imaging and surgery and the risk of recurrent stroke. Neurology 65:371-375, 2005

56. Fiebach JB, Schellinger PD, Gass A, Kucinski T, Siebler M, Villringer A, et al: Stroke magnetic resonance imaging is accurate in hyperacute intracerebral hemorrhage: a multicenter study on the validity of stroke imaging. Stroke 35:502-506, 2004

57. Fiebach JB, Schellinger PD, Jansen O, Meyer M, Wilde P, Bender J, et al: CT and diffusion-weighted MR imaging in randomized order: diffusion-weighted imaging results in higher accuracy and lower interrater variability in the diagnosis of hyperacute ischemic stroke. Stroke 33:2206-2210, 2002

58. Fiehler J, Albers GW, Boulanger JM, Derex L, Gass A, Hjort $\mathrm{N}$, et al: Bleeding risk analysis in stroke imaging before thromboLysis (BRASIL): pooled analysis of T2*-weighted magnetic resonance imaging data from 570 patients. Stroke 38:2738-2744, 2007 
59. Fisher M, Adams RD: Observations on brain embolism with special reference to the mechanism of hemorrhagic infarction. J Neuropathol Exp Neurol 10:92-94, 1951

60. Furlan AJ, Eyding D, Albers GW, Al-Rawi Y, Lees KR, Rowley HA, et al: Dose Escalation of Desmoteplase for Acute Ischemic Stroke (DEDAS): evidence of safety and efficacy 3 to 9 hours after stroke onset. Stroke 37:1227-1231, 2006

61. Geroulakos G, Ramaswami G, Nicolaides A, James K, Labropoulos N, Belcaro G, et al: Characterization of symptomatic and asymptomatic carotid plaques using high-resolution realtime ultrasonography. Br J Surg 80:1274-1277, 1993

62. Ginsberg MD, Pulsinelli WA: The ischemic penumbra, injury thresholds, and the therapeutic window for acute stroke. Ann Neurol 36:553-554, 1994

63. Go AS, Mozaffarian D, Roger VL, Benjamin EJ, Berry JD, Borden WB, et al: Heart disease and stroke statistics-2013 update: a report from the American Heart Association. Circulation 127:e6-e245, 2013

64. González RG, Koroshetz W, Pryor J: Introduction to acute stroke imaging and intervention. Semin Roentgenol 37:180181,2002

65. González RG, Schaefer PW, Buonanno FS, Schwamm LH, Budzik RF, Rordorf G, et al: Diffusion-weighted MR imaging: diagnostic accuracy in patients imaged within 6 hours of stroke symptom onset. Radiology 210:155-162, 1999

66. Graf J, Skutta B, Kuhn FP, Ferbert A: Computed tomographic angiography findings in 103 patients following vascular events in the posterior circulation: potential and clinical relevance. J Neurol 247:760-766, 2000

67. Grandin CB: Assessment of brain perfusion with MRI: methodology and application to acute stroke. Neuroradiology 45:755-766, 2003

68. Grotta JC, Chiu D, Lu M, Patel S, Levine SR, Tilley BC, et al: Agreement and variability in the interpretation of early $\mathrm{CT}$ changes in stroke patients qualifying for intravenous rtPA therapy. Stroke 30:1528-1533, 1999

69. Gubitz G, Sandercock P, Counsell C: Anticoagulants for acute ischaemic stroke. Cochrane Database Syst Rev (3): CD000024, 2004

70. Hacke W, Albers G, Al-Rawi Y, Bogousslavsky J, Davalos A, Eliasziw M, et al: The Desmoteplase in Acute Ischemic Stroke Trial (DIAS): a phase II MRI-based 9-hour window acute stroke thrombolysis trial with intravenous desmoteplase. Stroke 36:66-73, 2005

71. Hacke W, Furlan AJ, Al-Rawi Y, Davalos A, Fiebach JB, Gruber F, et al: Intravenous desmoteplase in patients with acute ischaemic stroke selected by MRI perfusion-diffusion weighted imaging or perfusion CT (DIAS-2): a prospective, randomised, double-blind, placebo-controlled study. Lancet Neurol 8:141-150, 2009

72. Hacke W, Kaste M, Bluhmki E, Brozman M, Dávalos A, Guidetti D, et al: Thrombolysis with alteplase 3 to 4.5 hours after acute ischemic stroke. N Engl J Med 359:1317-1329, 2008

73. Hacke W, Kaste M, Fieschi C, Toni D, Lesaffre E, von Kummer R, et al: Intravenous thrombolysis with recombinant tissue plasminogen activator for acute hemispheric stroke. JAMA 274:1017-1025, 1995

74. Hacke W, Schwab S, Horn M, Spranger M, De Georgia M, von Kummer R: 'Malignant' middle cerebral artery territory infarction: clinical course and prognostic signs. Arch Neurol 53:309-315, 1996

75. Hatsukami TS, Ross R, Polissar NL, Yuan C: Visualization of fibrous cap thickness and rupture in human atherosclerotic carotid plaque in vivo with high-resolution magnetic resonance imaging. Circulation 102:959-964, 2000

76. Heinsius T, Bogousslavsky J, Van Melle G: Large infarcts in the middle cerebral artery territory. Etiology and outcome patterns. Neurology 50:341-350, 1998

77. Heiss WD, Sobesky J, Hesselmann V: Identifying thresholds for penumbra and irreversible tissue damage. Stroke 35 (11 Suppl 1):2671-2674, 2004

78. Higashida RT, Furlan AJ, Roberts H, Tomsick T, Connors B, Barr J, et al: Trial design and reporting standards for intra-arterial cerebral thrombolysis for acute ischemic stroke. Stroke 34:e109-e137, 2003

79. Hirai T, Korogi Y, Ono K, Nagano M, Maruoka K, Uemura $\mathrm{S}$, et al: Prospective evaluation of suspected stenoocclusive disease of the intracranial artery: combined MR angiography and $\mathrm{CT}$ angiography compared with digital subtraction angiography. AJNR Am J Neuroradiol 23:93-101, 2002

80. Hom J, Dankbaar JW, Soares BP, Schneider T, Cheng SC, Bredno J, et al: Blood-brain barrier permeability assessed by perfusion $\mathrm{CT}$ predicts symptomatic hemorrhagic transformation and malignant edema in acute ischemic stroke. AJNR Am J Neuroradiol 32:41-48, 2011

81. Horie N, Morikawa M, Ishizaka S, Takeshita T, So G, Hayashi $\mathrm{K}$, et al: Assessment of carotid plaque stability based on the dynamic enhancement pattern in plaque components with multidetector CT angiography. Stroke 43:393-398, 2012

82. Hornig CR, Bauer T, Simon C, Trittmacher S, Dorndorf W: Hemorrhagic transformation in cardioembolic cerebral infarction. Stroke 24:465-468, 1993

83. Hornig CR, Dorndorf W, Agnoli AL: Hemorrhagic cerebral infarction-a prospective study. Stroke 17:179-185, 1986

84. Horowitz SH, Zito JL, Donnarumma R, Patel M, Alvir J: Computed tomographic-angiographic findings within the first five hours of cerebral infarction. Stroke 22:1245-1253, 1991

85. Horstmann S, Koziol JA, Martinez-Torres F, Nagel S, Gardner $\mathrm{H}$, Wagner S: Sonographic monitoring of mass effect in stroke patients treated with hypothermia. Correlation with intracranial pressure and matrix metalloproteinase 2 and 9 expression. J Neurol Sci 276:75-78, 2009

86. Hossmann KA: Viability thresholds and the penumbra of focal ischemia. Ann Neurol 36:557-565, 1994

87. Hwang DY, Silva GS, Furie KL, Greer DM: Comparative sensitivity of computed tomography vs. magnetic resonance imaging for detecting acute posterior fossa infarct. J Emerg Med 42:559-565, 2012

88. Jacobs L, Kinkel WR, Heffner RR Jr: Autopsy correlations of computerized tomography: experience with 6,000 CT scans. Neurology 26:1111-1118, 1976

89. Jäger HR, Moore EA, Bynevelt M, Coley S, Mounfield P, Kitchen N, et al: Contrast-enhanced MR angiography in patients with carotid artery stenosis: comparison of two different techniques with an unenhanced 2D time-of-flight sequence. Neuroradiology 42:240-248, 2000

90. Jansen O, Schellinger P, Fiebach J, Hacke W, Sartor K: Early recanalisation in acute ischaemic stroke saves tissue at risk defined by MRI. Lancet 353:2036-2037, 1999

91. Jaramillo A, Góngora-Rivera F, Labreuche J, Hauw JJ, Amarenco P: Predictors for malignant middle cerebral artery infarctions: a postmortem analysis. Neurology 66:815-820, 2006

92. Jauch EC, Cucchiara B, Adeoye O, Meurer W, Brice J, Chan YY, et al: American Heart Association guidelines for cardiopulmonary resuscitation and emergency cardiovascular care. Part 11: adult stroke. Circulation 122 (18 Suppl 3):S818S828, 2010

93. Jauch EC, Saver JL, Adams HP Jr, Bruno A, Connors JJ, Demaerschalk BM, et al: Guidelines for the early management of patients with acute ischemic stroke: a guideline for healthcare professionals from the American Heart Association/American Stroke Association. Stroke 44:870-947, 2013

94. Johnston DC, Goldstein LB: Clinical carotid endarterectomy decision making: noninvasive vascular imaging versus angiography. Neurology 56:1009-1015, 2001

95. Johnston SC, Gress DR, Browner WS, Sidney S: Short-term prognosis after emergency department diagnosis of TIA. JAMA 284:2901-2906, 2000 


\section{E. Tong et al.}

96. Johnston SC, Rothwell PM, Nguyen-Huynh MN, Giles MF, Elkins JS, Bernstein AL, et al: Validation and refinement of scores to predict very early stroke risk after transient ischaemic attack. Lancet 369:283-292, 2007

97. Kablau M, Kreisel SH, Sauer T, Binder J, Szabo K, Hennerici MG, et al: Predictors and early outcome of hemorrhagic transformation after acute ischemic stroke. Cerebrovasc Dis 32:334-341, 2011

98. Kakuda W, Thijs VN, Lansberg MG, Bammer R, Wechsler L, Kemp S, et al: Clinical importance of microbleeds in patients receiving IV thrombolysis. Neurology 65:1175-1178, 2005

99. Kamalian S, Kamalian S, Maas MB, Goldmacher GV, Payabvash S, Akbar A, et al: CT cerebral blood flow maps optimally correlate with admission diffusion-weighted imaging in acute stroke but thresholds vary by postprocessing platform. Stroke 42:1923-1928, 2011

100. Kang DW, Kwon JY, Kwon SU, Kim JS: Wake-up or unclear-onset strokes: are they waking up to the world of thrombolysis therapy? Int J Stroke 7:311-320, 2012

101. Kasner SE, Demchuk AM, Berrouschot J, Schmutzhard E, Harms L, Verro P, et al: Predictors of fatal brain edema in massive hemispheric ischemic stroke. Stroke 32:2117-2123, 2001

102. Katz DA, Marks MP, Napel SA, Bracci PM, Roberts SL: Circle of Willis: evaluation with spiral CT angiography, MR angiography, and conventional angiography. Radiology 195: 445-449, 1995

103. Kidwell CS, Alger JR, Di Salle F, Starkman S, Villablanca $\mathrm{P}$, Bentson J, et al: Diffusion MRI in patients with transient ischemic attacks. Stroke 30:1174-1180, 1999

104. Kidwell CS, Alger JR, Saver JL: Beyond mismatch: evolving paradigms in imaging the ischemic penumbra with multimodal magnetic resonance imaging. Stroke 34:2729-2735, 2003

105. Kidwell CS, Chalela JA, Saver JL, Starkman S, Hill MD, Demchuk AM, et al: Comparison of MRI and CT for detection of acute intracerebral hemorrhage. JAMA 292:18231830,2004

106. Kidwell CS, Jahan R, Alger JR, Schaewe TJ, Guzy J, Starkman $S$, et al: Design and rationale of the Mechanical Retrieval and Recanalization of Stroke Clots Using Embolectomy (MR RESCUE) Trial. Int J Stroke [epub ahead of print], 2012

107. Kidwell CS, Jahan R, Gornbein J, Alger JR, Nenov V, Ajani $Z$, et al: A trial of imaging selection and endovascular treatment for ischemic stroke. N Engl J Med 368:914-923, 2013

108. Kim SJ, Noh HJ, Yoon CW, Kim KH, Jeon P, Bang OY, et al: Multiphasic perfusion computed tomography as a predictor of collateral flow in acute ischemic stroke: comparison with digital subtraction angiography. Eur Neurol 67:252-255, 2012

109. Kimura K, Iguchi Y, Shibazaki K, Kobayashi K, Uemura J, Aoki J, et al: Recanalization between 1 and 24 hours after t-PA therapy is a strong predictor of cerebral hemorrhage in acute ischemic stroke patients. J Neurol Sci 270:48-52, 2008

110. Kloska SP, Nabavi DG, Gaus C, Nam EM, Klotz E, Ringelstein EB, et al: Acute stroke assessment with CT: do we need multimodal evaluation? Radiology 233:79-86, 2004

111. Knauth M, von Kummer R, Jansen O, Hähnel S, Dörfler A, Sartor K: Potential of CT angiography in acute ischemic stroke. AJNR Am J Neuroradiol 18:1001-1010, 1997

112. Koelemay MJ, Nederkoorn PJ, Reitsma JB, Majoie CB: Systematic review of computed tomographic angiography for assessment of carotid artery disease. Stroke 35:2306-2312, 2004

113. Köhrmann M, Schellinger PD: Stroke-MRI: extending the time-window: recent trials and clinical practice. Int J Stroke 2:53-54, 2007

114. Korosec FR, Frayne R, Grist TM, Mistretta CA: Time-resolved contrast-enhanced 3D MR angiography. Magn Reson Med 36: 345-351, 1996
115. Krieger DW, Demchuk AM, Kasner SE, Jauss M, Hantson L: Early clinical and radiological predictors of fatal brain swelling in ischemic stroke. Stroke 30:287-292, 1999

116. Kucharczyk J, Mintorovitch J, Asgari HS, Moseley M: Diffusion/perfusion MR imaging of acute cerebral ischemia. Magn Reson Med 19:311-315, 1991

117. Kucinski T, Koch C, Grzyska U, Freitag HJ, Krömer H, Zeumer $\mathrm{H}$ : The predictive value of early $\mathrm{CT}$ and angiography for fatal hemispheric swelling in acute stroke. AJNR Am J Neuroradiol 19:839-846, 1998

118. Kunte H, Schmidt C, Harms L, Rückert RI, Grigoryev M, Fischer T: Contrast-enhanced ultrasound and detection of carotid plaque neovascularization. Neurology 79:2081, 2012

119. Labeyrie MA, Turc G, Hess A, Hervo P, Mas JL, Meder JF, et al: Diffusion lesion reversal after thrombolysis: a MR correlate of early neurological improvement. Stroke 43: 2986-2991, 2012

120. Lansberg MG, Lee J, Christensen S, Straka M, De Silva DA, Mlynash M, et al: RAPID automated patient selection for reperfusion therapy: a pooled analysis of the Echoplanar Imaging Thrombolytic Evaluation Trial (EPITHET) and the Diffusion and Perfusion Imaging Evaluation for Understanding Stroke Evolution (DEFUSE) Study. Stroke 42:1608-1614, 2011

121. Lansberg MG, Straka M, Kemp S, Mlynash M, Wechsler LR, Jovin TG, et al: MRI profile and response to endovascular reperfusion after stroke (DEFUSE 2): a prospective cohort study. Lancet Neurol 11:860-867, 2012

122. Larrue V, von Kummer R R, Müller A, Bluhmki E: Risk factors for severe hemorrhagic transformation in ischemic stroke patients treated with recombinant tissue plasminogen activator: a secondary analysis of the European-Australasian Acute Stroke Study (ECASS II). Stroke 32:438-441, 2001

123. Lee LJ, Kidwell CS, Alger J, Starkman S, Saver JL: Impact on stroke subtype diagnosis of early diffusion-weighted magnetic resonance imaging and magnetic resonance angiography. Stroke 31:1081-1089, 2000

124. Lee SH, Kang BS, Kim N, Roh JK: Does microbleed predict haemorrhagic transformation after acute atherothrombotic or cardioembolic stroke? J Neurol Neurosurg Psychiatry 79: 913-916, 2008

125. Lees KR, Bluhmki E, von Kummer R, Brott TG, Toni D, Grotta JC, et al: Time to treatment with intravenous alteplase and outcome in stroke: an updated pooled analysis of ECASS, ATLANTIS, NINDS, and EPITHET trials. Lancet 375:16951703,2010

126. Lennard NS, Vijayasekar C, Tiivas C, Chan CW, Higman $\mathrm{DJ}$, Imray $\mathrm{CH}$ : Control of emboli in patients with recurrent or crescendo transient ischaemic attacks using preoperative transcranial Doppler-directed Dextran therapy. Br J Surg 90: 166-170, 2003

127. Leys D, Pruvo JP, Godefroy O, Rondepierre P, Leclerc X: Prevalence and significance of hyperdense middle cerebral artery in acute stroke. Stroke 23:317-324, 1992

128. Liebeskind DS: Collateral circulation. Stroke 34:2279-2284, 2003

129. Liebeskind DS: Collaterals in acute stroke: beyond the clot. Neuroimaging Clin N Am 15:553-573, x, 2005

130. Liebeskind DS, Sanossian N: How well do blood flow imaging and collaterals on angiography predict brain at risk? Neurology 79 (13 Suppl 1):S105-S109, 2012

131. Liebeskind DS, Sanossian N, Yong WH, Starkman S, Tsang MP, Moya AL, et al: CT and MRI early vessel signs reflect clot composition in acute stroke. Stroke 42:1237-1243, 2011

132. Liebeskind DS, Sansing LH: Willisian collateralization. Neurology 63:344, 2004

133. Lim RP, Shapiro M, Wang EY, Law M, Babb JS, Rueff LE, et al: 3D time-resolved MR angiography (MRA) of the carotid arteries with time-resolved imaging with stochastic trajectories: comparison with 3D contrast-enhanced Bolus-Chase 
MRA and 3D time-of-flight MRA. AJNR Am J Neuroradiol 29:1847-1854, 2008

134. Lindley RI, Wardlaw JM, Sandercock PA, Rimdusid P, Lewis SC, Signorini DF, et al: Frequency and risk factors for spontaneous hemorrhagic transformation of cerebral infarction. J Stroke Cerebrovasc Dis 13:235-246, 2004

135. Linfante I, Llinas RH, Schlaug G, Chaves C, Warach S, Caplan LR: Diffusion-weighted imaging and National Institutes of Health Stroke Scale in the acute phase of posterior-circulation stroke. Arch Neurol 58:621-628, 2001

136. Lodder J: CT-detected hemorrhagic infarction; relation with the size of the infarct, and the presence of midline shift. Acta Neurol Scand 70:329-335, 1984

137. Lodder J, Krijne-Kubat B, Broekman J: Cerebral hemorrhagic infarction at autopsy: cardiac embolic cause and the relationship to the cause of death. Stroke 17:626-629, 1986

138. Long A, Lepoutre A, Corbillon E, Branchereau A: Critical review of non- or minimally invasive methods (duplex ultrasonography, MR- and CT-angiography) for evaluating stenosis of the proximal internal carotid artery. Eur J Vasc Endovasc Surg 24:43-52, 2002

139. Lövblad KO, Laubach HJ, Baird AE, Curtin F, Schlaug G, Edelman RR, et al: Clinical experience with diffusionweighted MR in patients with acute stroke. AJNR Am J Neuroradiol 19:1061-1066, 1998

140. Ma H, Parsons MW, Christensen S, Campbell BC, Churilov L, Connelly A, et al: A multicentre, randomized, double-blinded, placebo-controlled Phase III study to investigate EXtending the time for Thrombolysis in Emergency Neurological Deficits (EXTEND). Int J Stroke 7:74-80, 2012

141. Malm J, Bergenheim AT, Enblad P, Hårdemark HG, Koskinen LO, Naredi S, et al: The Swedish Malignant Middle Cerebral Artery Infarction Study: long-term results from a prospective study of hemicraniectomy combined with standardized neurointensive care. Acta Neurol Scand 113: 25-30, 2006

142. Manno EM, Nichols DA, Fulgham JR, Wijdicks EF: Computed tomographic determinants of neurologic deterioration in patients with large middle cerebral artery infarctions. Mayo Clin Proc 78: 156-160, 2003

143. Maramattom BV, Bahn MM, Wijdicks EF: Which patient fares worse after early deterioration due to swelling from hemispheric stroke? Neurology 63:2142-2145, 2004

144. Marder VJ, Chute DJ, Starkman S, Abolian AM, Kidwell C, Liebeskind D, et al: Analysis of thrombi retrieved from cerebral arteries of patients with acute ischemic stroke. Stroke 37:2086-2093, 2006

145. Marks MP, de Crespigny A, Lentz D, Enzmann DR, Albers GW, Moseley ME: Acute and chronic stroke: navigated spinecho diffusion-weighted MR imaging. Radiology 199:403408, 1996

146. Markus HS, Droste DW, Kaps M, Larrue V, Lees KR, Siebler M, et al: Dual antiplatelet therapy with clopidogrel and aspirin in symptomatic carotid stenosis evaluated using doppler embolic signal detection: the Clopidogrel and Aspirin for Reduction of Emboli in Symptomatic Carotid Stenosis (CARESS) trial. Circulation 111:2233-2240, 2005

147. Mayer TE, Hamann GF, Baranczyk J, Rosengarten B, Klotz E, Wiesmann M, et al: Dynamic CT perfusion imaging of acute stroke. AJNR Am J Neuroradiol 21: 1441-1449, 2000

148. Menon BK, O'Brien B, Bivard A, Spratt NJ, Demchuk AM, Miteff F, et al: Assessment of leptomeningeal collaterals using dynamic CT angiography in patients with acute ischemic stroke. J Cereb Blood Flow Metab 33:365-371, 2013

149. Mitsumori LM, Hatsukami TS, Ferguson MS, Kerwin WS, Cai J, Yuan C: In vivo accuracy of multisequence MR imaging for identifying unstable fibrous caps in advanced human carotid plaques. J Magn Reson Imaging 17:410-420, 2003

150. Mlynash M, Lansberg MG, De Silva DA, Lee J, Christensen
S, Straka M, et al: Refining the definition of the malignant profile: insights from the DEFUSE-EPITHET pooled data set. Stroke 42:1270-1275, 2011

151. Mlynash M, Olivot JM, Tong DC, Lansberg MG, Eyngorn I, Kemp S, et al: Yield of combined perfusion and diffusion MR imaging in hemispheric TIA. Neurology 72:1127-1133, 2009

152. Moftakhar P, English JD, Cooke DL, Kim WT, Stout C, Smith WS, et al: Density of thrombus on admission CT predicts revascularization efficacy in large vessel occlusion acute ischemic stroke. Stroke 44:243-245, 2013

153. Naghavi M, Libby P, Falk E, Casscells SW, Litovsky S, Rumberger J, et al: From vulnerable plaque to vulnerable patient: a call for new definitions and risk assessment strategies: Part II. Circulation 108:1772-1778, 2003

154. Narisawa A, Shamoto H, Shimizu H, Tominaga T, Yoshimoto T: [Diffusion-weighted magnetic resonance imaging (MRI) in acute brain stem infarction.] No To Shinkei 53:10211026, 2001 (Jpn)

155. National Institute of Neurological Disorders and Stroke rt-PA Stroke Study Group: Tissue plasminogen activator for acute ischemic stroke. . N Engl J Med 333:1581-1587, 1995

156. Nederkoorn PJ, Mali WP, Eikelboom BC, Elgersma OE, Buskens E, Hunink MG, et al: Preoperative diagnosis of carotid artery stenosis: accuracy of noninvasive testing. Stroke 33:2003-2008, 2002

157. Nguyen-Huynh MN, Wintermark M, English J, Lam J, Vittinghoff E, Smith WS, et al: How accurate is CT angiography in evaluating intracranial atherosclerotic disease? Stroke 39: 1184-1188, 2008

158. Nicoli F, Lafaye de Micheaux P, Girard N: Perfusionweighted imaging-derived collateral flow index is a predictor of MCA M1 recanalization after i.v. thrombolysis. AJNR Am J Neuroradiol 34: 107-114, 2013

159. Nogueira RG, Lutsep HL, Gupta R, Jovin TG, Albers GW, Walker GA, et al: Trevo versus Merci retrievers for thrombectomy revascularisation of large vessel occlusions in acute ischaemic stroke (TREVO 2): a randomised trial. Lancet 380:1231-1240, 2012

160. Ogawa A, Mori E, Minematsu K, Taki W, Takahashi A, Nemoto S, et al: Randomized trial of intraarterial infusion of urokinase within 6 hours of middle cerebral artery stroke: the middle cerebral artery embolism local fibrinolytic intervention trial (MELT) Japan. Stroke 38:2633-2639, 2007

161. Okada Y, Yamaguchi T, Minematsu K, Miyashita T, Sawada $\mathrm{T}$, Sadoshima S, et al: Hemorrhagic transformation in cerebral embolism. Stroke 20:598-603, 1989

162. Olivot JM, Mlynash M, Thijs VN, Kemp S, Lansberg MG, Wechsler L, et al: Optimal Tmax threshold for predicting penumbral tissue in acute stroke. Stroke 40:469-475, 2009

163. Oppenheim C, Samson Y, Manaï R, Lalam T, Vandamme $\mathrm{X}$, Crozier S, et al: Prediction of malignant middle cerebral artery infarction by diffusion-weighted imaging. Stroke 31: 2175-2181, 2000

164. Paciaroni M, Agnelli G, Corea F, Ageno W, Alberti A, Lanari A, et al: Early hemorrhagic transformation of brain infarction: rate, predictive factors, and influence on clinical outcome: results of a prospective multicenter study. Stroke 39:2249-2256, 2008

165. Pantano P, Caramia F, Bozzao L, Dieler C, von Kummer R: Delayed increase in infarct volume after cerebral ischemia: correlations with thrombolytic treatment and clinical outcome. Stroke 30:502-507, 1999

166. Patel SC, Levine SR, Tilley BC, Grotta JC, Lu M, Frankel $\mathrm{M}$, et al: Lack of clinical significance of early ischemic changes on computed tomography in acute stroke. JAMA 286:2830-2838, 2001

167. Paxton R, Ambrose J: The EMI scanner. A brief review of the first 650 patients. Br J Radiol 47:530-565, 1974 
168. Payabvash S, Souza LC, Wang Y, Schaefer PW, Furie $\mathrm{KL}$, Halpern EF, et al: Regional ischemic vulnerability of the brain to hypoperfusion: the need for location specific computed tomography perfusion thresholds in acute stroke patients. Stroke 42:1255-1260, 2011

169. Penumbra Pivotal Stroke Trial Investigators: The Penumbra Pivotal Stroke Trial: safety and effectiveness of a new generation of mechanical devices for clot removal in intracranial large vessel occlusive disease. Stroke 40:2761-2768, 2009

170. Perkins CJ, Kahya E, Roque CT, Roche PE, Newman GC: Fluid-attenuated inversion recovery and diffusion- and perfusion-weighted MRI abnormalities in 117 consecutive patients with stroke symptoms. Stroke 32:2774-2781, 2001

171. Pessin MS, Del Zoppo GJ, Estol CJ: Thrombolytic agents in the treatment of stroke. Clin Neuropharmacol 13:271-289, 1990

172. Purroy F, Montaner J, Rovira A, Delgado P, Quintana M, Alvarez-Sabín J: Higher risk of further vascular events among transient ischemic attack patients with diffusion-weighted imaging acute ischemic lesions. Stroke 35:2313-2319, 2004

173. Qiao Y, Etesami M, Astor BC, Zeiler SR, Trout HH III, Wasserman BA: Carotid plaque neovascularization and hemorrhage detected by MR imaging are associated with recent cerebrovascular ischemic events. AJNR Am J Neuroradiol 33:755-760, 2012

174. Randoux B, Marro B, Koskas F, Duyme M, Sahel M, Zouaoui A, et al: Carotid artery stenosis: prospective comparison of $\mathrm{CT}$, three-dimensional gadolinium-enhanced MR, and conventional angiography. Radiology 220:179-185, 2001

175. Rerkasem K, Rothwell PM: Carotid endarterectomy for symptomatic carotid stenosis. Cochrane Database Syst Rev (4):CD001081, 2011

176. Restrepo L, Jacobs MA, Barker PB, Wityk RJ: Assessment of transient ischemic attack with diffusion- and perfusionweighted imaging. AJNR Am J Neuroradiol 25:1645-1652, 2004

177. Rha JH, Saver JL: The impact of recanalization on ischemic stroke outcome: a meta-analysis. Stroke 38:967-973, 2007

178. Rodríguez-Yáñez M, Castellanos M, Blanco M, Millán M, Nombela F, Sobrino T, et al: Micro- and macroalbuminuria predict hemorrhagic transformation in acute ischemic stroke. Neurology 67:1172-1177, 2006

179. Romero JM, Babiarz LS, Forero NP, Murphy EK, Schaefer PW, Gonzalez RG, et al: Arterial wall enhancement overlying carotid plaque on CT angiography correlates with symptoms in patients with high grade stenosis. Stroke 40: 1894-1896, 2009

180. Rothwell PM, Eliasziw M, Gutnikov SA, Fox AJ, Taylor DW, Mayberg MR, et al: Analysis of pooled data from the randomised controlled trials of endarterectomy for symptomatic carotid stenosis. Lancet 361:107-116, 2003

181. Ryoo JW, Na DG, Kim SS, Lee KH, Lee SJ, Chung CS, et al: Malignant middle cerebral artery infarction in hyperacute ischemic stroke: evaluation with multiphasic perfusion computed tomography maps. J Comput Assist Tomogr 28: 55-62, 2004

182. Saba L, Anzidei M, Marincola BC, Piga M, Raz E, Bassareo PP, et al: Imaging of the carotid artery vulnerable plaque. Cardiovasc Intervent Radiol [epub ahead of print], 2013

183. Saba L, Caddeo G, Sanfilippo R, Montisci R, Mallarini G: $\mathrm{CT}$ and ultrasound in the study of ulcerated carotid plaque compared with surgical results: potentialities and advantages of multidetector row CT angiography. AJNR Am J Neuroradiol 28: 1061-1066, 2007

184. Saba L, Caddeo G, Sanfilippo R, Montisci R, Mallarini G: Efficacy and sensitivity of axial scans and different reconstruction methods in the study of the ulcerated carotid plaque using multidetector-row CT angiography: comparison with surgical results. AJNR Am J Neuroradiol 28:716-723, 2007
185. Saba L, Lai ML, Montisci R, Tamponi E, Sanfilippo R, Faa $\mathrm{G}$, et al: Association between carotid plaque enhancement shown by multidetector CT angiography and histologically validated microvessel density. Eur Radiol 22:2237-2245, 2012

186. Saba L, Mallarini G: Carotid plaque enhancement and symptom correlations: an evaluation by using multidetector row CT angiography. AJNR Am J Neuroradiol 32:1919-1925, 2011

187. Saba L, Piga M, Raz E, Farina D, Montisci R: Carotid artery plaque classification: does contrast enhancement play a significant role? AJNR Am J Neuroradiol 33:1814-1817, 2012

188. Saba L, Sanfilippo R, Montisci R, Atzeni M, Ribuffo D, Mallarini G: Vulnerable plaque: detection of agreement between multi-detector-row CT angiography and US-ECD. Eur J Radiol 77:509-515, 2011

189. Saba L, Sanfilippo R, Sannia S, Anzidei M, Montisci R, Mallarini G, et al: Association between carotid artery plaque volume, composition, and ulceration: a retrospective assessment with MDCT. AJR Am J Roentgenol 199:151-156, 2012

190. Saqqur M, Uchino K, Demchuk AM, Molina CA, Garami Z, Calleja S, et al: Site of arterial occlusion identified by transcranial Doppler predicts the response to intravenous thrombolysis for stroke. Stroke 38:948-954, 2007

191. Saver JL: Hemorrhage after thrombolytic therapy for stroke: the clinically relevant number needed to harm. Stroke 38: 2279-2283, 2007

192. Saver JL: Intra-arterial fibrinolysis for acute ischemic stroke: the message of melt. Stroke 38:2627-2628, 2007

193. Saver JL, Jahan R, Levy EI, Jovin TG, Baxter B, Nogueira $\mathrm{RG}$, et al: Solitaire flow restoration device versus the Merci Retriever in patients with acute ischaemic stroke (SWIFT): a randomised, parallel-group, non-inferiority trial. Lancet 380:1241-1249, 2012

194. Schaefer PW, Grant PE, Gonzalez RG: Diffusion-weighted MR imaging of the brain. Radiology 217:331-345, 2000

195. Schellinger PD, Bryan RN, Caplan LR, Detre JA, Edelman RR, Jaigobin C, et al: Evidence-based guideline: the role of diffusion and perfusion MRI for the diagnosis of acute ischemic stroke: report of the Therapeutics and Technology Assessment Subcommittee of the American Academy of Neurology. Neurology 75:177-185, 2010

196. Schellinger PD, Fiebach JB, Hacke W: Imaging-based decision making in thrombolytic therapy for ischemic stroke: present status. Stroke 34:575-583, 2003

197. Schonewille WJ, Tuhrim S, Singer MB, Atlas SW: Diffusionweighted MRI in acute lacunar syndromes. A clinical-radiological correlation study. Stroke 30:2066-2069, 1999

198. Schwarz F, Bayer-Karpinska A, Poppert H, Buchholz M, Cyran C, Grimm J, et al: Serial carotid MRI identifies rupture of a vulnerable plaque resulting in amaurosis fugax. Neurology 80:1171-1172, 2013

199. Shrier DA, Tanaka H, Numaguchi Y, Konno S, Patel U, Shibata D: CT angiography in the evaluation of acute stroke. AJNR Am J Neuroradiol 18:1011-1020, 1997

200. Sims JR, Rordorf G, Smith EE, Koroshetz WJ, Lev MH, Buonanno F, et al: Arterial occlusion revealed by CT angiography predicts NIH stroke score and acute outcomes after IV tPA treatment. AJNR Am J Neuroradiol 26:246-251, 2005

201. Smith WS, Sung G, Saver J, Budzik R, Duckwiler G, Liebeskind DS, et al: Mechanical thrombectomy for acute ischemic stroke: final results of the Multi MERCI trial. Stroke 39:1205-1212, 2008

202. Sobesky J, Zaro Weber O, Lehnhardt FG, Hesselmann V, Neveling M, Jacobs A, et al: Does the mismatch match the penumbra? Magnetic resonance imaging and positron emission tomography in early ischemic stroke. Stroke 36:980985,2005 
203. Sohn CH, Sevick RJ, Frayne R: Contrast-enhanced MR angiography of the intracranial circulation. Magn Reson Imaging Clin N Am 11:599-614, 2003

204. Srinivasan A, Goyal M, Al Azri F, Lum C: State-of-the-art imaging of acute stroke. Radiographics 26 (Suppl 1):S75S95, 2006

205. Tan JC, Dillon WP, Liu S, Adler F, Smith WS, Wintermark M: Systematic comparison of perfusion-CT and CT-angiography in acute stroke patients. Ann Neurol 61:533-543, 2007

206. ten Kate GL, van den Oord SC, Sijbrands EJ, van der Lugt A, de Jong N, Bosch JG, et al: Current status and future developments of contrast-enhanced ultrasound of carotid atherosclerosis. J Vasc Surg 57:539-546, 2013

207. Tenser MS, Amar AP, Mack WJ: Mechanical thrombectomy for acute ischemic stroke using the MERCI retriever and Penumbra Aspiration systems. World Neurosurg 76 (6 Suppl):S16-S23, 2011

208. Terruso V, D’Amelio M, Di Benedetto N, Lupo I, Saia V, Famoso G, et al: Frequency and determinants for hemorrhagic transformation of cerebral infarction. Neuroepidemiology 33:261-265, 2009

209. Thomalla G, Cheng B, Ebinger M, Hao Q, Tourdias T, Wu $\mathrm{O}$, et al: DWI-FLAIR mismatch for the identification of patients with acute ischaemic stroke within $4.5 \mathrm{~h}$ of symptom onset (PRE-FLAIR): a multicentre observational study. Lancet Neurol 10:978-986, 2011

210. Thomalla G, Ebinger M, Fiehler J, Fiebach JB, Endres M, Gerloff C: [EU-funded treatment study: WAKE-UP: a randomized, placebo-controlled MRI-based trial of thrombolysis in wake-up stroke.] Nervenarzt 83:1241-1251, 2012 (Ger)

211. Thomalla G, Rossbach P, Rosenkranz M, Siemonsen S, Krützelmann A, Fiehler J, et al: Negative fluid-attenuated inversion recovery imaging identifies acute ischemic stroke at 3 hours or less. Ann Neurol 65:724-732, 2009

212. Toni D, Fiorelli M, Bastianello S, Sacchetti ML, Sette G, Argentino C, et al: Hemorrhagic transformation of brain infarct: predictability in the first 5 hours from stroke onset and influence on clinical outcome. Neurology 46:341-345, 1996

213. van Gils MJ, Homburg PJ, Rozie S, de Weert TT, Dippel DW, van der Lugt A: Evolution of atherosclerotic carotid plaque morphology: do ulcerated plaques heal? A serial multidetector CT angiography study. Cerebrovasc Dis 31:263-270, 2011

214. Verro P, Tanenbaum LN, Borden NM, Sen S, Eshkar N: CT angiography in acute ischemic stroke: preliminary results. Stroke 33:276-278, 2002

215. Viallon M, Altrichter S, Pereira VM, Nguyen D, Sekoranja L, Federspiel A, et al: Combined use of pulsed arterial spinlabeling and susceptibility-weighted imaging in stroke at 3T. Eur Neurol 64:286-296, 2010

216. Videen TO, Zazulia AR, Manno EM, Derdeyn CP, Adams $\mathrm{RE}$, Diringer $\mathrm{MN}$, et al: Mannitol bolus preferentially shrinks non-infarcted brain in patients with ischemic stroke. Neurology 57:2120-2122, 2001

217. von Kummer R, Bourquain H, Bastianello S, Bozzao L, Manelfe C, Meier D, et al: Early prediction of irreversible brain damage after ischemic stroke at CT. Radiology 219: 95-100, 2001

218. von Kummer R, Meyding-Lamadé U, Forsting M, Rosin L,
Rieke K, Hacke W, et al: Sensitivity and prognostic value of early CT in occlusion of the middle cerebral artery trunk. AJNR Am J Neuroradiol 15:9-18, 1994

219. von Kummer R, Nolte PN, Schnittger H, Thron A, Ringelstein EB: Detectability of cerebral hemisphere ischaemic infarcts by CT within 6 h of stroke. Neuroradiology 38:31-33, 1996

220. Wahlgren N, Ahmed N, Eriksson N, Aichner F, Bluhmki E, Dávalos A, et al: Multivariable analysis of outcome predictors and adjustment of main outcome results to baseline data profile in randomized controlled trials: Safe Implementation of Thrombolysis in Stroke-MOnitoring STudy (SITSMOST). Stroke 39:3316-3322, 2008

221. Warach S, Gaa J, Siewert B, Wielopolski P, Edelman RR: Acute human stroke studied by whole brain echo planar diffusion-weighted magnetic resonance imaging. Ann Neurol 37: 231-241, 1995

222. Wildermuth S, Knauth M, Brandt T, Winter R, Sartor K, Hacke W: Role of CT angiography in patient selection for thrombolytic therapy in acute hemispheric stroke. Stroke 29:935-938, 1998

223. Wintermark M, Flanders AE, Velthuis B, Meuli R, van Leeuwen M, Goldsher D, et al: Perfusion-CT assessment of infarct core and penumbra: receiver operating characteristic curve analysis in 130 patients suspected of acute hemispheric stroke. Stroke 37:979-985, 2006

224. Wintermark M, Jawadi SS, Rapp JH, Tihan T, Tong E, Glidden DV, et al: High-resolution CT imaging of carotid artery atherosclerotic plaques. AJNR Am J Neuroradiol 29: 875-882, 2008

225. Wintermark M, Maeder P, Thiran JP, Schnyder P, Meuli R: Quantitative assessment of regional cerebral blood flows by perfusion CT studies at low injection rates: a critical review of the underlying theoretical models. Eur Radiol 11:1220-1230, 2001

226. Wintermark M, Reichhart M, Thiran JP, Maeder P, Chalaron M, Schnyder P, et al: Prognostic accuracy of cerebral blood flow measurement by perfusion computed tomography, at the time of emergency room admission, in acute stroke patients. Ann Neurol 51:417-432, 2002

227. Wolpert SM, Bruckmann H, Greenlee R, Wechsler L, Pessin MS, del Zoppo GJ: Neuroradiologic evaluation of patients with acute stroke treated with recombinant tissue plasminogen activator. The rt-PA Acute Stroke Study Group. AJNR Am J Neuroradiol 14:3-13, 1993

228. Zhou Y, Xing Y, Li Y, Bai Y, Chen Y, Sun X, et al: An assessment of the vulnerability of carotid plaques: a comparative study between intraplaque neovascularization and plaque echogenicity. BMC Med Imaging 13:13, 2013

Manuscript submitted September 10, 2013.

Accepted October 30, 2013.

Please include this information when citing this paper: DOI: 10.3171/2013.10.FOCUS13396.

Address correspondence to: Max Wintermark, M.D., UVA Department of Radiology, Neuroradiology Division, Box 800170 , Charlottesville, VA 22908. email: Max.Wintermark@gmail.com. 